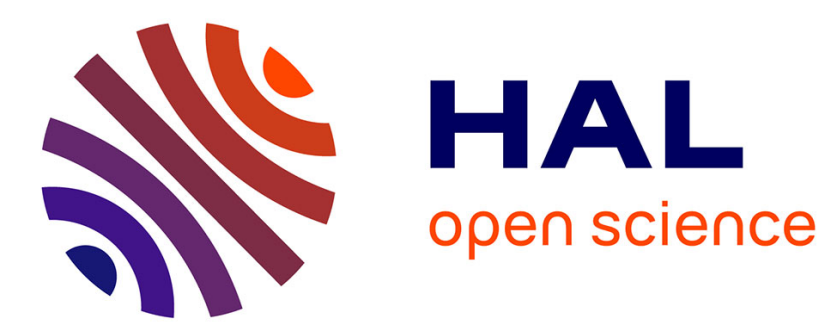

\title{
Tectonothermal Evolution of the Cameros Basin: Implications for Tectonics of North Iberia
}

J. Rat, F. Mouthereau, S. Brichau, A. Crémades, M. Bernet, M. Balvay, J. Ganne, Abdeltif Lahfid, C. Gautheron

\section{- To cite this version:}

J. Rat, F. Mouthereau, S. Brichau, A. Crémades, M. Bernet, et al.. Tectonothermal Evolution of the Cameros Basin: Implications for Tectonics of North Iberia. Tectonics, 2019, 38 (2), pp.440-469. 10.1029/2018TC005294 . hal-02110330

\section{HAL Id: hal-02110330 \\ https://hal.science/hal-02110330}

Submitted on 26 Mar 2021

HAL is a multi-disciplinary open access archive for the deposit and dissemination of scientific research documents, whether they are published or not. The documents may come from teaching and research institutions in France or abroad, or from public or private research centers.
L'archive ouverte pluridisciplinaire HAL, est destinée au dépôt et à la diffusion de documents scientifiques de niveau recherche, publiés ou non, émanant des établissements d'enseignement et de recherche français ou étrangers, des laboratoires publics ou privés. 


\section{Tectonics}

\section{RESEARCH ARTICLE \\ 10.1029/2018TC005294 \\ Key Points: \\ - Iberian Range thermal history provides record of the tectonic evolution of the Iberia-Europe plate boundary \\ - Zircon grains cooled during rifting events are preserved in the Ebro basin detrital record \\ - Diachronous Iberian Range and Pyrenean rifting events recorded the same Albian thermal anomaly and metamorphism}

Supporting Information:

- Supporting Information S1

- Table S1

- Table S2

Correspondence to:

J. Rat,

juliette.rat@get.omp.eu

Citation:

Rat, J., Mouthereau, F., Brichau, S., Crémades, A., Bernet, M., Balvay, M., et al. (2019). Tectonothermal evolution of the Cameros basin: Implications for tectonics of North Iberia. Tectonics, 38, 440-469. https://doi.org/10.1029/ 2018TC005294

Received 21 AUG 2018

Accepted 28 DEC 2018

Accepted article online 2 JAN 2019

Published online 1 FEB 2019

(C)2019. American Geophysical Union. All Rights Reserved.

\section{Tectonothermal Evolution of the Cameros Basin: Implications for Tectonics of North Iberia}

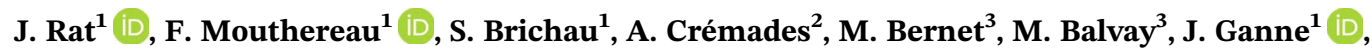 \\ A. Lahfid ${ }^{4}$, and C. Gautheron ${ }^{5}$ \\ ${ }^{1}$ Géosciences Environnement Toulouse, Université de Toulouse, UPS, Université Paul Sabatier, CNRS, IRD, Toulouse, \\ France, ${ }^{2}$ CRPG, UMR 7358 CNRS, Université de Lorraine, Vandoeuvre-lès-Nancy, France, ${ }^{3}$ Institut des Sciences de la \\ Terre, Université Grenoble Alpes, CNRS, Grenoble, France, ${ }^{4}$ BRGM, Orléans, France, ${ }^{5}$ GEOPS, Université Paris-Sud, \\ CNRS, Université Paris-Saclay, Orsay, France
}

\begin{abstract}
Constraining the way in which continental deformation is accommodated in time and space is essential to reconcile past plate movements with geological observations. Kinematic reconstructions of the Iberia-Europe plate boundary are still debated. Here we focus on an inverted Mesozoic rift basin, the Cameros basin, which is part of the Iberian chain. We use a combination of detrital low-temperature thermochronological techniques to define the time-temperature evolution of the basin from Mesozoic rifting to Cenozoic collision. Zircon fission-track analyses of Oligocene-Miocene sedimentary rocks yield two main age populations at $\sim 170 \pm 10$ and $\sim 100 \pm 10 \mathrm{Ma}$, reflecting (i) an Early Jurassic thermal event related to the Atlantic-Alpine Tethys opening and (ii) an Albo-Cenomanian thermal event related to the Bay of Biscay opening. Thermal modeling of combined zircon fission-track, apatite fission-track, and apatite

(U-Th-Sm)/He data reveals that collision-related cooling of the Cameros basin started during the Paleocene ( $\sim 60 \mathrm{Ma}$ ). A second cooling/exhumation phase of the basin is recorded from 35 to $25 \mathrm{Ma}$. Initial cooling occurred after a protracted postrift period characterized by persistence of high geothermal gradients, a feature also recognized in the Pyrenees. Our results show that the Iberian chain shared the same Early to Late Jurassic tectonothermal evolution with the Atlantic-Alpine Tethyan rifted margins. From the Albian onward, the thermal evolution of the Cameros basin was very similar to that of the Pyrenees. This study shows that the preservation in mountain ranges of a succession of rifting events provide important clues for plate reconstructions.
\end{abstract}

\section{Introduction}

The Africa-Europe plate boundary in Iberia evolved through a complex tectonic and thermal evolution that started at the Permian-Triassic boundary with the fragmentation of the Gondwana margin and extension that followed the Hercynian collisional orogeny (Schettino \& Turco, 2011; Stampfli \& Borel, 2002; Zielger, 1989). By the Early-Middle Jurassic, the connection of the Central Atlantic spreading ridges with the Alpine-Tethys domain led to the development of a transform plate boundary in southern Iberia, between Europe and Africa. In the Late Jurassic-Early Cretaceous, extension shifted to northern Iberia, which ultimately led to seafloor spreading in the Bay of Biscay during the Aptian-Albian and the individualization of the Iberia plate along the Iberia-Europe plate boundary (IEPB). The general picture of main tectonic events is relatively well constrained on the southern and northern Iberia margins. Yet there is a strong debate on the details of the Late Jurassic-Early Cretaceous kinematics of the IEPB (Barnett-Moore et al., 2016; Jammes et al., 2009; Olivet, 1996; Vissers et al., 2016; Vissers \& Meijer, 2012). Clues for understanding the Iberian plate kinematics have been raised in recent studies by introducing a kinematic boundary south of the Ebro crustal block (Nirrengarten et al., 2018; Tugend et al., 2015). In these models, the required Late Jurassic-Early Cretaceous sinistral strike-slip displacement between Europe and Iberia is partly accommodated in the Central Iberian rift system by a presumably complex pattern of extension, parallel and orthogonal to the IEPB (Figure 1). The consideration of intra-Iberia shortening associated with tectonic inversion of the Iberian rift system has been proven to be essential for refining plate reconstructions of Western Mediterranean evolution and distinguishing between kinematic models of plate convergence in the Pyrenees (Mouthereau et al., 2014; Van Hinsbergen et al., 2014). 


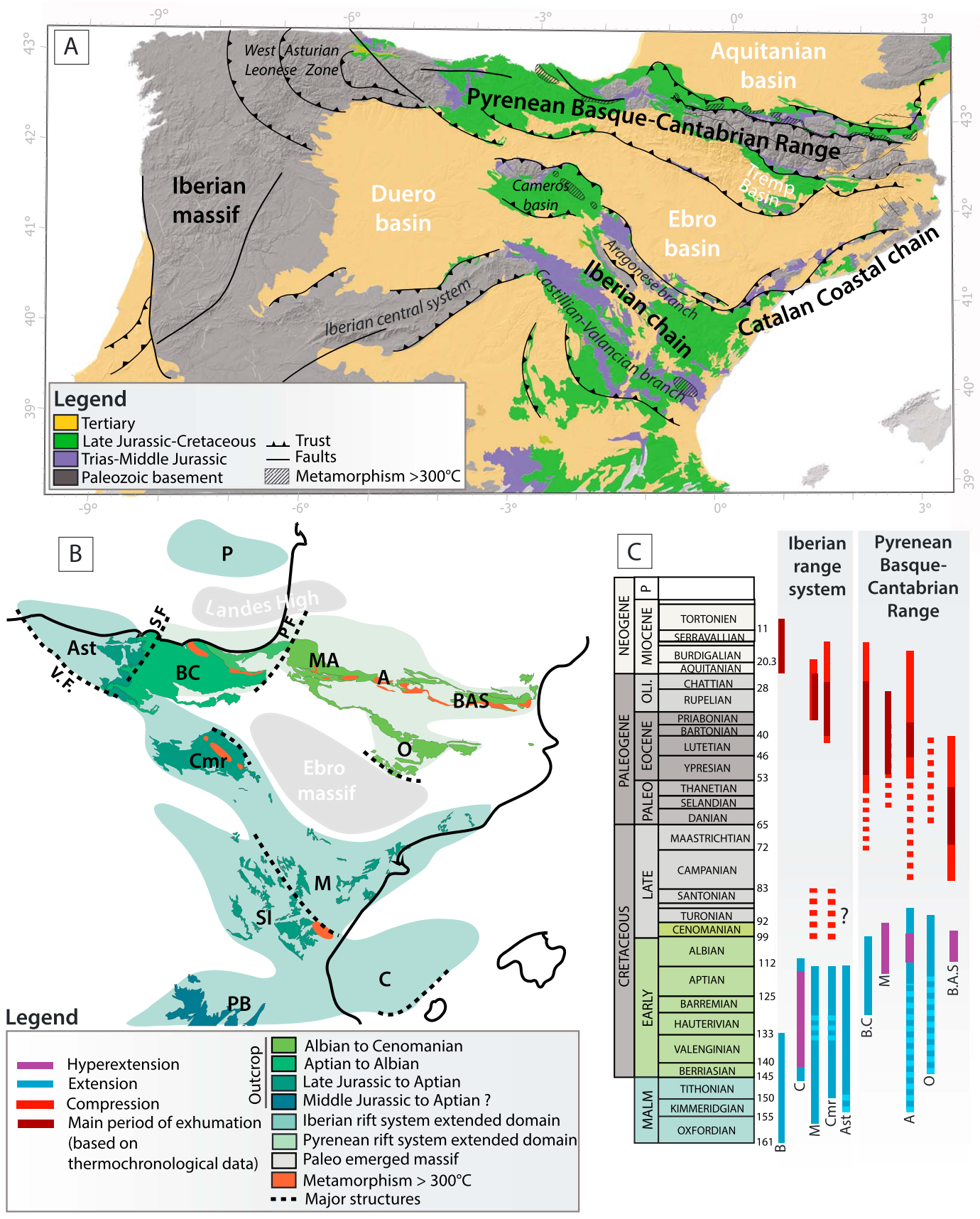

Figure 1. North Iberia geological setting. (a) Simplified geological map of North Iberia modified from the $1 / 10^{6}$ scale geological map of Spain available online at info.igme.es. (b) Location of Late Jurassic-Early to Late Cretaceous rift basins and their respective ages after Tugend et al. (2015). (c) Deformation history of North Iberia modified after Tugend et al. (2015). Metamorphic domains are compiled after Clerc et al. (2015) and Salas et al. (1995). Ast = Asturian Basin; $\mathrm{A}=$ Aulus Basin; $\mathrm{BC}=$ Basque-Cantabrian Basin; BAS = Boucheville-Agly-St Paul Basin; $\mathrm{Cmr}=$ Cameros basin; $\mathrm{C}=$ Columbret Basin; $\mathrm{M}=$ Maestrat Basin; $\mathrm{MA}=$ Mauleon Arzac $; \mathrm{O}=$ Organya Basin $\mathrm{P}=$ Parentis Basin; $\mathrm{PF}=$ Pamplona Fault; PB = Pre-Betic basin; SF = Santander Fault; SI = South Iberian Basin; VF = Ventaniella Fault.

The Iberia plate appears to be an ideal place where to examine the physical conditions of long-term crustal strain localization leading to collisional plate boundary formation. In this study, we focus on the Cameros basin of the Central Iberian rift system, which was inverted to form the northwestern tip of the Iberian chain. We aim at providing constraints on the thermal evolution of the Cameros rift basin and the adjacent Ebro foreland basin. A combination of well-suited detrital low-temperature thermochronometers, including 
apatite (U-Th-Sm)/He (AHe), zircon fission-track (ZFT), and apatite fission-track (AFT) analyses, is applied to study the thermal history of the Cameros basin and of the sediment source areas during rifting and tectonic inversion stages. We complement a former study by Del Río, Barbero, and Stuart (2009) in the Cameros basin and extend it to the higher-temperature ZFT thermochronometers reliable for provenance analyses of detrital deposits and to gain resolution of precollisional cooling events. We further provide new fission-track analyses from the Cenozoic sediments of the Ebro basin in order to assess the Oligocene exhumation and provenance of clastic sediments from adjacent massifs and to allow comparison with the Cameros thermal record. This study allows us to derive a first-order model of local versus plate-scale cooling and exhumation and to stress the importance of thermal anomalies recorded by sediments over the orogenic cycle. Our results are discussed to improve the current understanding of intraplate deformation and the mechanisms controlling the evolution of the IEPB.

\section{The Iberian Chain: Inverted Mesozoic Basins South of the Ebro Block}

The Iberian chain forms a NW-SE oriented doubly vergent intraplate mountain belt south of the Ebro basin (Figure 1a). It resulted from the tectonic inversion of a series of Mesozoic rift basins comprising from east to west the Columbret, Asturian, Basque-Cantabrian, Maestrat, south Iberian, and Cameros basins (Etheve et al., 2018; Roca \& Guimerà, 1992; Salas et al., 2001; Salas \& Casas, 1993; Figure 1). Two successive extensional phases are documented in the rift basins, the first one from Permian to Hettangian and the second one from the Late Jurassic to Early Cretaceous times (Salas et al., 2001). The first thinning event is a large-scale and synchronous feature. It represents the record of continental rifting in Iberia related to the opening of the Atlantic and the Alpine-Ligurian Tethys oceans (Péron-Pinvidic et al., 2007; Tucholke et al., 2007; Tugend et al., 2014). The second rifting phase is thought to result from the reactivation of the former NW-SE striking Iberian rift system connecting the Atlantic and Alpine-Tethyan domains (Bulard, 1972). This late rift evolution is diachronous along the strike of the belt and has close temporal relationships with the tectonic evolution of the Pyrenean-Basque-Cantabrian rift basins and opening of the Bay of Biscay. For instance, the onset of rapid subsidence in the Maestrat basin occurred during the early Oxfordian but was delayed to the late Oxfordian to Tithonian in the other basins of the Iberian rift system (Salas et al., 2001; Figures 1b and 1c). The Aptian signed the end of extension in the Asturian Basin and the onset of rapid subsidence in the Basque-Cantabrian Basin (García-Mondéjar et al., 1996; Rat, 1988). At the same time, the depocenter migrated toward the north in the Cameros basin. Extension shifted to the northern boundary of the Ebro block, in the Pyrenean rift, during the Albian-Cenomanian (Tugend et al., 2015; Vergés \& García-Senz, 2001). The onset of sea floor spreading during the Albian in the Bay of Biscay and mantle exhumation in the Pyrenean basin indicates crustal strain localization at the plate boundary between Europe and Iberia (Jammes et al., 2010; Lagabrielle \& Bodinier, 2008; Mouthereau et al., 2014; Tugend et al., 2014).

Crustal thicknesses derived from gravity data vary from $32 \mathrm{~km}$ on the northern and southern borders of the Iberian Range to a maximum of $43 \mathrm{~km}$ in the center (Salas et al., 2001), which are in the range of the crustal thicknesses inferred from seismic profiles (Díaz \& Gallart, 2009). Mesozoic thinning is constrained in the Maestrat Basin where an initial crustal thickness of 23-26 km equivalent to $40 \mathrm{~km}$ of extension or a cumulative stretching factor $\beta=1.37$ are inferred (Salas et al., 2001). However, as noted by Salas et al. (2001), the important variability in Mesozoic sedimentary infill throughout the Iberian chain implies a variability in crustal thinning as well. For instance, the Valencia through (Columbrets Basin) preserves a 10-km-thick Mesozoic succession overlying an extremely thinned continental crust of less than $4 \mathrm{~km}$ (Etheve et al., 2018). Iberian rift basins are predominantly infilled by shallow-marine carbonate deposits, although significant clastic supply is preserved in marginal areas such as the Cameros basin (Salas et al., 2001). The transition from synrift to postrift phases is marked by the deposition of white sandstones of the Utrillas Formation that came from Ordovician metasedimentary rocks and orthogneisses, Permian volcanic rocks, and Triassic sandstones from the Iberian massif during intense weathering (González-Acebrón et al., 2017).

The transition recorded in the Iberian rift basins is proposed to reflect the evolution from a left lateral transtensional system in northern Iberia, including the Ebro block from the Late Jurassic-Early Cretaceous times, to localized orthogonal extension during the Albian in the Pyrenees (Nirrengarten et al., 2017, 2018; Tugend et al., 2015). According to this model, about $70 \mathrm{~km}$ of extension is accommodated in the Iberian rift system, whereas almost $100 \mathrm{~km}$ of extension is resolved in the Pyrenean rift system. The second Albian-Cenomanian 
extension, which led to crustal hyperextension and mantle exhumation in the Pyrenees is outlined by a contemporaneous low-to-very low metamorphic event that not only is well expressed in the Cameros basin but is also described in the Maestrat Basin (Casquet et al., 1992; Salas et al., 2005; Figure 1b).

The onset of convergence in the Iberian rift basin is poorly constrained. There is evidence of Late Cretaceous compressional deformation in the Cameros basin, although some authors suggested that it perhaps reflects a far-field effect of Pyrenean rift extension (Casas-Sainz \& Gil-Imaz, 1998). For comparison, the signature of the initiation of collision in the Pyrenees occurred in the Late Cretaceous ( $70 \mathrm{Ma}$ ) as recorded by the onset of cooling in siliciclastic sediments of the northeastern Pyrenees and subsidence pattern (Mouthereau et al., 2014; Rougier et al., 2016). A regional cooling event from 50 to $35 \mathrm{Ma}$ is recorded throughout the Pyrenees that signs the paroxysm of collision in the Pyrenees and positive feedback between erosion and tectonics (Vacherat et al., 2016, 2017). Low-temperature thermochronology data in the Cameros basin further suggest the onset of mature collisional orogeny from the early Eocene to the Oligocene (Del Río, Barbero, \& Stuart, 2009). Shortening ceased in the Cameros basin in the Tortonian-Messinian (late Miocene) as evidenced by undeformed sediments overlying the northern Cameros thrust (Figure 2; Muñoz-Jiménez \& Casas-Sainz, 1997). Across the northern branch of the Iberian chain (Figure 1), a total shortening of $57 \mathrm{~km}$ is estimated (Salas et al., 2001), distributed between $38 \mathrm{~km}$ of shortening in the Cameros basin (Guimerà et al., 1995) and $19 \mathrm{~km}$ of shortening across the Aragonese branch and the Castillian-Valencian branch (Guimerà, 1988; Salas et al., 2001). Across the southwestern part of the Iberian chain, shortening is supposed to have reached $75 \pm 12 \mathrm{~km}$ (Salas et al., 2001).

\section{Cameros Basin}

The Cameros basin is located in the northwestern extremity of the Iberian chain. It forms an asymmetric sag basin $120 \mathrm{~km}$ long and $90 \mathrm{~km}$ wide, which contains Late Jurassic to Early Cretaceous synrift sediments with a maximum thickness of 6.5 km (Mas et al., 2011; Omodeo Salè et al., 2014) to 8 km (Casas-Sainz \& Gil-Imaz, 1998; García-Lasanta et al., 2017; Figures 2a and 2b). Two thrust fronts separate the Mesozoic basin from the Cenozoic Ebro and the Duero basins to the north and to the south, respectively. The Cameros basin is surrounded by the Demanda and Montecayo massifs located to the west and east, respectively. These two massifs are made of Paleozoic and Triassic rocks (Figure 2a). The Cameros basin was affected by Alpine shortening of $38 \mathrm{~km}$, which is mostly taken up by the Cameros northern front thrust (Salas et al., 2001; Figures $2 \mathrm{c}$ and $3 \mathrm{a}$ ). A maximum vertical thickness of $3.5 \mathrm{~km}$ of Eocene to Oligocene alluvial and fluvial sediments are currently present in the footwall of the northern thrust (Muñoz-Jiménez \& Casas-Sainz, 1997; Figure 2c).

\subsection{Stratigraphy and Depositional Environments}

The Cameros basin depositional sequences are characterized by sandstones, claystones, and limestones deposited in lacustrine, alluvial, and fluvial environments as well as coastal wet land with episodic marine incursions (Alonso \& Mas, 1993; Guiraud \& Seguret, 1985; Mas et al., 2011; Quijada et al., 2010; Suárez González et al., 2010). Sedimentation occurred during two successive synrift episodes of high subsidence rates from 151 to142 Ma (Tithonian-Early Berriasian) and during 129-109 Ma (Barremian-Early Aptian; Omodeo-Salé et al., 2017). Synrift sediments are classically subdivided into five "Wealdian-type" lithostratigraphic units comprising the Tera, Oncala, Urbion, Enciso, and Olivan Groups from bottom to top, respectively (Beuther, 1966; Tischer, 1966). Each sequence thins progressively toward the north above the prerift Early Jurassic carbonate substratum (Figure 2c), arguing for an apparent northward migration of the basin depocenter during extension. Below the northern tectonic limit of the Cameros basin, the postrift sequence consists of $100 \mathrm{~m}$ of late Albian-Cenomanian sandstones (Utrillas Formation) and 200-m-thick Late Cretaceous marine limestone. In the south, the Late Cretaceous sequence reached $500 \mathrm{~m}(200 \mathrm{~m}$ of Utrillas sandstones overlain by $300 \mathrm{~m}$ of marine limestone). Above the Cameros basin, a maximum thickness of $\sim 700 \mathrm{~m}$ is estimated for the overall late Albian to Paleocene postrift sequence deposits (Omodeo Salé et al., 2014; Salas \& Casas, 1993). Borehole data at the thrust front (Arnedo-1 and Demanda-1) show a lack of Wealdian-type sedimentary sequences, whereas further north (Rioja-1) in the Ebro foreland basin these deposits are 250-800 m thick (Lanaja, 1987).

Alternative stratigraphy architectures have been proposed for the synrift deposits (e.g., Omodeo-Salé et al., 2014) based on the recognition of depositional sequences. Although the lithostratigraphy may not resolve 


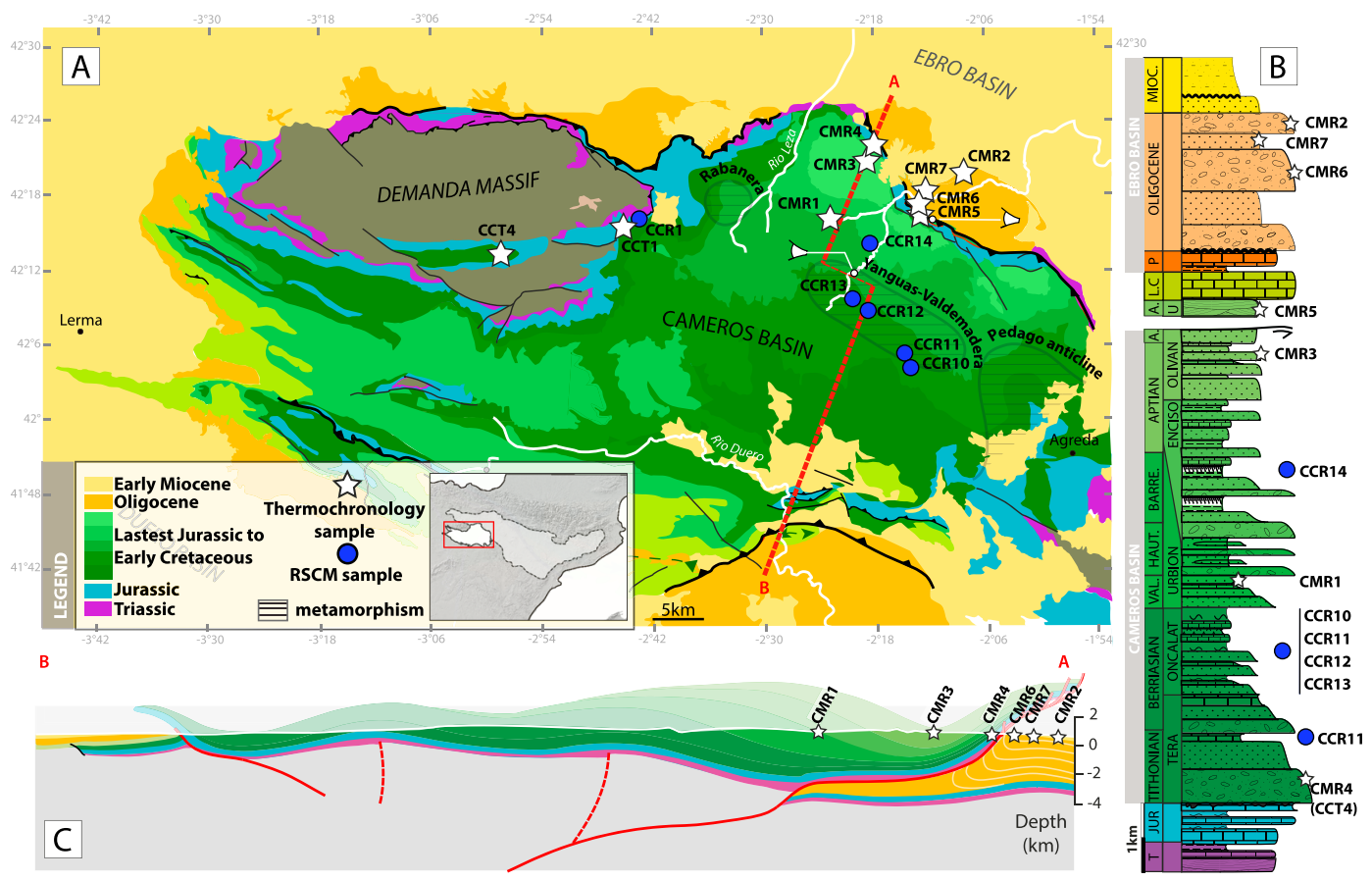

Figure 2. Geological map and stratigraphy of the Cameros basin modified from the 1:50.000 scale geological maps of Spain (Munilla map) included in the Magna50 series available for download at info.igme.es. (a) Geological map of Cameros including sample and cross-section locations. (b) Synthetic lithostratigraphic successions of the Cameros basin compiled after Mas et al. (2011) and Salas et al. (2001) and the adjacent Ebro basin. (c) North-south cross section of the Cameros basin with locations of low-temperature thermochronological samples and RSCM (Raman spectrometry on carbonaceous materials) constraints.

some details of the stratigraphy of the Cameros basin, we chose to refer to the lithostratigraphic subdivision used to argue the architecture presented in the structural model of Casas-Sainz and Gil-Imaz (1998). This model is taken as the structural model of reference from which our data are discussed. It should be noted that throughout the paper our depositional ages refer to the lithostratigraphic subdivisions presented on the 1/50.000 scale map of Munilla (see Figure 2).

\subsection{Structure of the Cameros Basin and Tectonic Models}

Seismic reflection profiles made across the Cameros basin and field measurements reveal the remarkable continuity of the prerift Jurassic and Triassic layers below the synrift sediments (Casas et al., 2000; Casas Sainz, 1993; Casas-Sainz \& Gil-Imaz, 1998; Casas-Sainz \& Simón-Gómez, 1992; Omodeo Salè et al., 2014; Figure 2c). The lack of normal faulting and the tilt of prerift strata onto the reactivated normal fault has questioned ways in which extension is accommodated. Another key observation is that synrift strata are the thinnest toward the northern margin of the basin near the contact with the putative reactivated normal fault (Figure 2c). This is at odds with a classical rolling-hinge model in which sediments are expected to thicken toward the fault. Three main tectonic models have been debated over the past 20 years to explain these observations. Guiraud \& Seguret (1985) proposed the Cameros basin formed as a syndepositional syncline, in which deformation and subsidence accommodated basement tilt and faulting by a detachment in the weak Triassic gypsum and clay layers. The proposed coexistence of synextensional compression structures (axial-fold cleavages) led the authors to propose the basin developed in a releasing bend along two hypothetical $\mathrm{N} 60^{\circ} \mathrm{E}$ sinistral strike-slip faults. The Alpine reactivation of the detachment and the basement fault to the north is considered as minor. Casas-Sainz and Gil-Imaz (1998) together with Casas et al. (2009) and García-Lasanta et al. (2017) consider the Cameros basin formed as an extensional syncline above a detachment in weak Triassic layers. A major difference from the previous model is that the thin-skinned detachment system roots at depth into the basement on a low-angle crustal detachment. This model better accounts for subsurface constraints attesting for $30 \mathrm{~km}$ of northward transport of the basin over the Ebro 

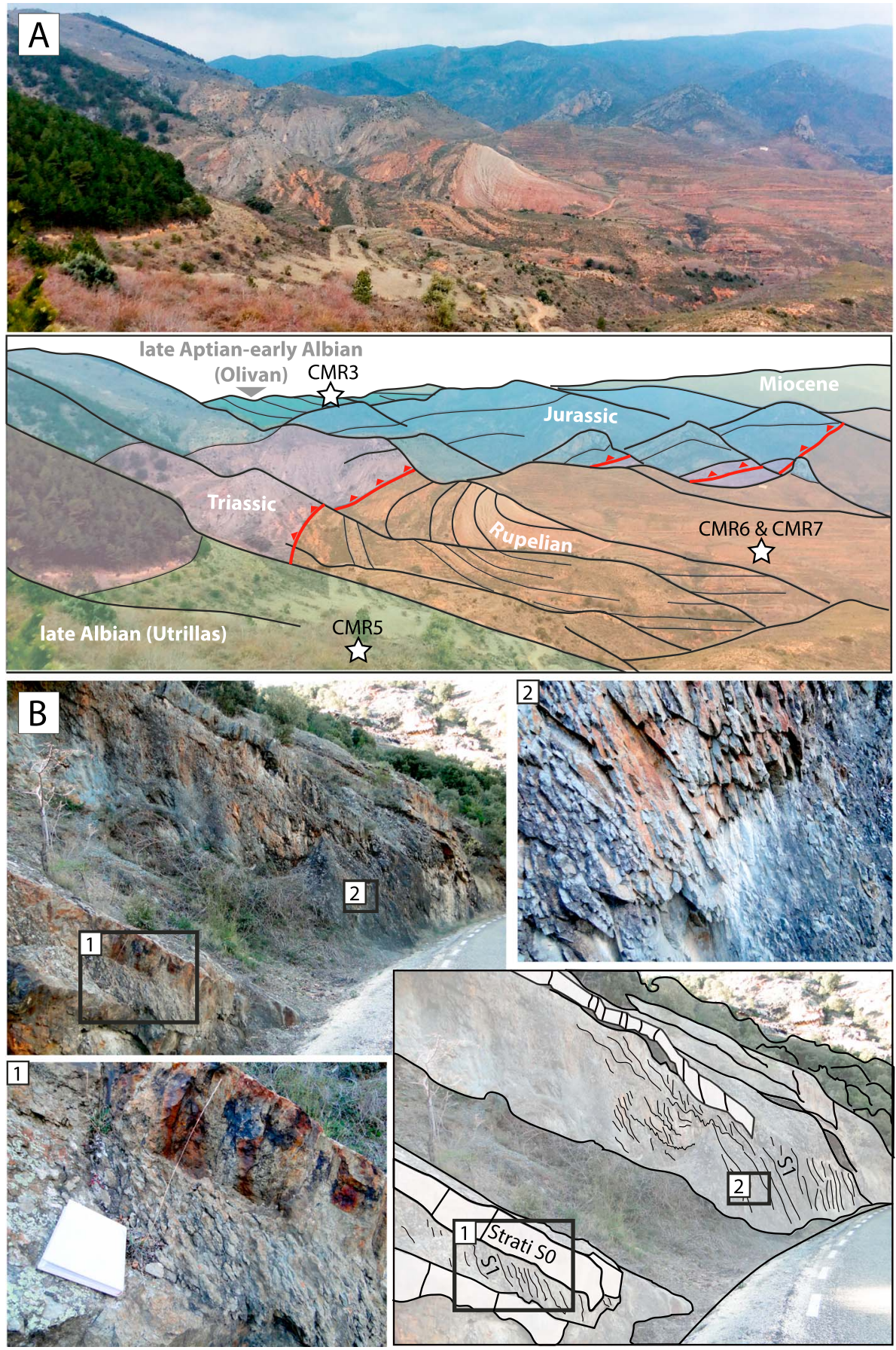

Figure 3. Field photographs of the Cameros basin (see Figure 2a for location). (a) Northern thrust front of the Cameros basin modified from Mas et al. (2011). Stars represent the approximate position of the sample. (b) Evidence for cleavages in the Urbion Group at the northern extremity of the Yanguas domain.

basin Cenozoic sediments. Casas-Sainz and Gil-Imaz (1998) explain the occurrence of Early Cretaceous shortening as the result of far-field stress transfer arising from the onset of seafloor spreading in the Bay of Biscay. For Mas et al. (1993), Guimerà et al. (1995), and Omodeo Salè et al. (2014) the Cameros basin results from the northward migration of the basin axis, controlled by the fault ramp located in the deep Paleozoic basement. While the syncline widens the synrift sediments onlap on the basin substratum. The 
thrust ramp responsible for the inversion of the basin is interpreted as a newly formed structure unrelated to the Mesozoic extension.

Despite their differences, all studies account for the occurrence of an extensional low-angle detachment at the base of the cover or/and in the basement. Here we do not intend to discuss the alternative models in detail but rather complement the set of available constraints by new thermochronological analyses in order to shed new lights on the tectonic and thermal evolution of the Cameros basin in the context of the IEPB evolution.

\subsection{Albian-Coniacian Metamorphism and Peak Temperature in the Cameros Basin}

The Cameros basin recorded low-to-very low greenschist facies metamorphism, indicated by the occurrence of chloritoid and pyrophyllite (Guiraud \& Seguret, 1985). Casquet et al. (1992) dated the metamorphism to 108-86 Ma (Albian-Coniacian) using K/Ar dating on authigenic illite. Metamorphism therefore postdates the main rifting events.

At first order, the metamorphic domain is limited to the north of the Oncala anticline (Figure 2a). Inside this domain, peak temperatures and distribution of metamorphic zones are highly heterogeneous as reflected by vitrinite reflectance (VR), chlorite thermometry, thermochronological, and fluid inclusions data (Del Río, Barbero, \& Stuart, 2009; Del Río, Barbero, Mata, \& Fanning, 2009; González-Acebrón et al., 2011; Omodeo-Salé et al., 2016, 2017). They can be defined by three NW-SE oriented zones: the YanguasValdemadera zone, the Rabanera River zone, and the Pegado anticline zone (Figure 2a). The YanguasValdemadera zone stretches $\sim 150 \mathrm{~km}$ and exhibits the highest temperatures $\left(350-370{ }^{\circ} \mathrm{C}\right.$; Mantilla Figueroa et al., 2002; Figures $2 \mathrm{~b}$ and $3 \mathrm{~b}$ ). The Rabanera River and Pegado anticline zones have a smaller extent and show temperatures between 195 and $350{ }^{\circ} \mathrm{C}$ (González-Acebrón et al., 2011; Mantilla Figueroa et al., 2002). The origin of the Albian-Coniacian metamorphism remains unclear, and factors invoked are dependent on the structural model considered. For instance, the model of Casas-Sainz and Gil-Imaz (1998) implies sediment thickness up to $8 \mathrm{~km}$, which provides support to burial as the main driving mechanism. Mas et al. (1993) in their model assume $6.5 \mathrm{~km}$ of total sediment thickness, hence minimizing the role of sediment burial (Guimerà et al., 1995).

In support of these different structural models, different paleogradients have been estimated. Based on fluid inclusions (Mata et al., 2001) and thermochronological data (Del Río, Barbero, \& Stuart, 2009), a minimal metamorphic paleothermal gradient of $\sim 70{ }^{\circ} \mathrm{C} / \mathrm{km}$ has been measured for the metamorphic domain assuming a sediment thickness of $8 \mathrm{~km}$. By contrast, based on subsidence data in the southern and northern Cameros basin, a lower paleogeothermal gradient of about $41.5^{\circ} \mathrm{C} / \mathrm{km}$ is derived from paleoheat flow value of $64 \mathrm{~mW} / \mathrm{m}^{2}$ obtained at the end of the postrift phase by Omodeo-Salé et al. (2017). They also infer based on 2-D thermal modeling that the Cameros basin experienced low crustal thinning. To explain high temperatures documented in the basin, they invoke the circulation of hot fluids, which is supported by the analyses of fluid inclusions and petrographic textures on the organic matter. In addition, the observation that more permeable sedimentary layers show higher metamorphic grade independent of their stratigraphic position supports close relationships between metamorphism and fluid pathways (Alonso-Azcàrate et al., 1995; Barrenechea et al., 2001; Mantilla Figueroa et al., 1998; Omodeo-Salé et al., 2017). Altogether, burial, high heat flow related to lithospheric thinning, and the occurrence of hot fluids certainly explain the AlbianConiacian metamorphism. However, the relative importance of the different factors is yet to be defined. A second phase of hydrothermal alteration has also been described and dated at $40 \pm 5 \mathrm{Ma}$ with illite K/Ar dating (Mantilla Figueroa et al., 2002). This second thermal event is well characterized in the eastern part of the Cameros basin in the Pegado anticline, and temperatures measured for this second peak range between 281 and $305^{\circ} \mathrm{C}$ (González-Acebrón et al., 2011). It is, however, still unclear if this event corresponds to a second fluid flow event or to cooling during Albian-Coniacian retrograde metamorphism (González-Acebrón et al., 2011; Mantilla Figueroa et al., 1998, 2002).

\subsection{Overview of Low-Temperature Constraints in Northern Iberia and the Cameros Basin} 3.4.1. Low-Temperature Thermochronology Data From the Cameros Basin

AFT data published by Del Río, Barbero, and Stuart (2009) form the basis of the thermochronological data set available in the Cameros basin. AFT age populations range from $21 \pm 5$ to $127 \pm 25 \mathrm{Ma}$. Except for the Olivan Group, all samples in Del Río's study systematically reveal AFT populations younger than the stratigraphic age, indicating that synrift samples have been heated to about $120^{\circ} \mathrm{C}$ during their postdepositional 
history. Del Río, Barbero, and Stuart (2009) also performed ZFT analyses on two samples from the Olivan (Aptian-Early Albian) and Urbion (Hauterivian-Valanginian) Groups. The Olivan sample yielded two ZFT grain age populations at 185 and $400 \mathrm{Ma}$, much older than the depositional age and therefore reflect cooling of source rocks. By contrast, a ZFT sample from the Urbion Group collected outside of the metamorphic domain yielded only one age component at $85 \pm 6 \mathrm{Ma}$. This age is younger than the stratigraphic age ( 135 Ma), suggesting heating of the sandstone at minimum temperature of $240 \pm 30{ }^{\circ} \mathrm{C}$. AHe dating performed on two samples from the south and north of the massif yielded six ages ranging from $31.1 \pm 1.5$ to $39.8 \pm 2.8 \mathrm{Ma}$. AFT, ZFT, and AHe cooling age populations are attributed to the first exhumation event of the massif at 55 to $40 \mathrm{Ma}$ and a second exhumation event at 40-30 Ma, corresponding to the main period of contraction in the Cameros basin (Muñoz-Jiménez \& Casas-Sainz, 1997).

3.4.2. Cooling History of Iberian Paleozoic and Mesozoic Massifs

The Cameros basin sediment source area characterization required the clarification of the Mesozoic cooling history of the main neighboring massif. The Iberian Paleozoic Massif in northwestern Iberia consists of Paleozoic sedimentary sequences intruded by late Hercynian plutons from 320 to 280 Ma (Figure 1). Based on the petrographic signature of sediments and SW-NE paleocurrent orientations, this domain is considered to be the main source of sediments deposited in the Mesozoic basins of northern Iberia and in particular the Cameros basin (Arribas et al., 2003; Ochoa et al., 2007; Tischer, 1966). The vertical motion of the source terrains is constrained by AFT data. Figures $4 \mathrm{a}$ and $4 \mathrm{~b}$ show Mesozoic cooling ages ranging from Early Triassic to Late Cretaceous and (200-83 Ma) ages cluster in the western part of the Iberian Paleozoic Massif. The age cluster become progressively older eastward in the Cantabrian belt where Triassic to Jurassic grain ages are documented. The west central Cantabrian Mountains exhibit a pattern of Late Cretaceous and Cenozoic AFT cooling ages.

Time-temperature paths inferred from inverse thermal modeling available from the literature allow resolving cooling history patterns for the Iberian Paleozoic Massif (Figure 4b). The Western Cantabrian massif reveals rapid cooling during two successive events in the Early and Late Jurassic at $190 \pm 20$ and $150 \pm 10 \mathrm{Ma}$ (Grobe et al., 2010; Figure 4b). A slower cooling history characterized by an onset of cooling in the Permian is inferred slightly to the east (Botor \& Anczkiewicz, 2015; Figure 4b). A more complex time-temperature history with less well resolved Early Jurassic to Late Cretaceous cooling events is documented in the central Iberian system (Bruijne \& Andriessen, 2002, Figure 4b). Permian to Early Cretaceous ZFT cooling ages reported in the Catalan coastal range are inferred to reflect several rifting episodes during Mesozoic (Juez-Larré \& Andriessen, 2006; Figures 4a and 4c). A large fraction reveals an Early to Middle Jurassic age possibly related to a reequilibration following the Triassic thermal pulse of the first Mesozoic rifting phase. Although of major kinematic importance for Iberia, the Aptian-Albian event can only be indirectly inferred from a small number of time-temperature paths from the central Iberian system (Bruijne \& Andriesen, 2002; Figure 4b).

Numerous low-temperature analyses over the last 20 years have been carried out in the Pyrenees (Bosch et al., 2016; Fitzgerald et al., 1999; Gibson et al., 2007; Gunnell et al., 2009; Herman et al., 2013; Jolivet et al., 2007; Labaume et al., 2016; Maurel et al., 2004, 2008; Mouchene, 2016; Sinclair et al., 2005; Vacherat et al., 2014, 2016; Yelland, 1991). They show that most of the AFT data yield early Eocene to late Oligocene cooling ages (Figure 4a).

However, thermal heating relative to the lithosphere thinning and the mantle exhumation are also well recorded in the Albian synrift sediments of the northern Pyrenees by ZHe and ZFT data (Figure 4c). For instance, thermal modeling performed in the Mauleon basin shows that a high temperature of $180{ }^{\circ} \mathrm{C}$ was maintained $30 \mathrm{Myr}$ after the onset of rifting at $\sim 110 \mathrm{Ma}$ (Vacherat et al., 2014). According to this study, the high thermal regime established during rifting is responsible for the delayed record of cooling during the Eocene although collision started in the Late Cretaceous. Only few Eocene to late Oligocene ZFT cooling ages are recorded in the eastern Pyrenees.

\section{Methods and Sampling Strategy}

\subsection{Low-Temperature Detrital ZFT, AFT, and AHe Analyses}

Seven sandstone samples were collected from synrift sedimentary rocks of the northern Cameros basin close to Arnedillo (Table 1 and Figure 2a). Samples CMR4, CMR1, and CMR3 were taken from the 

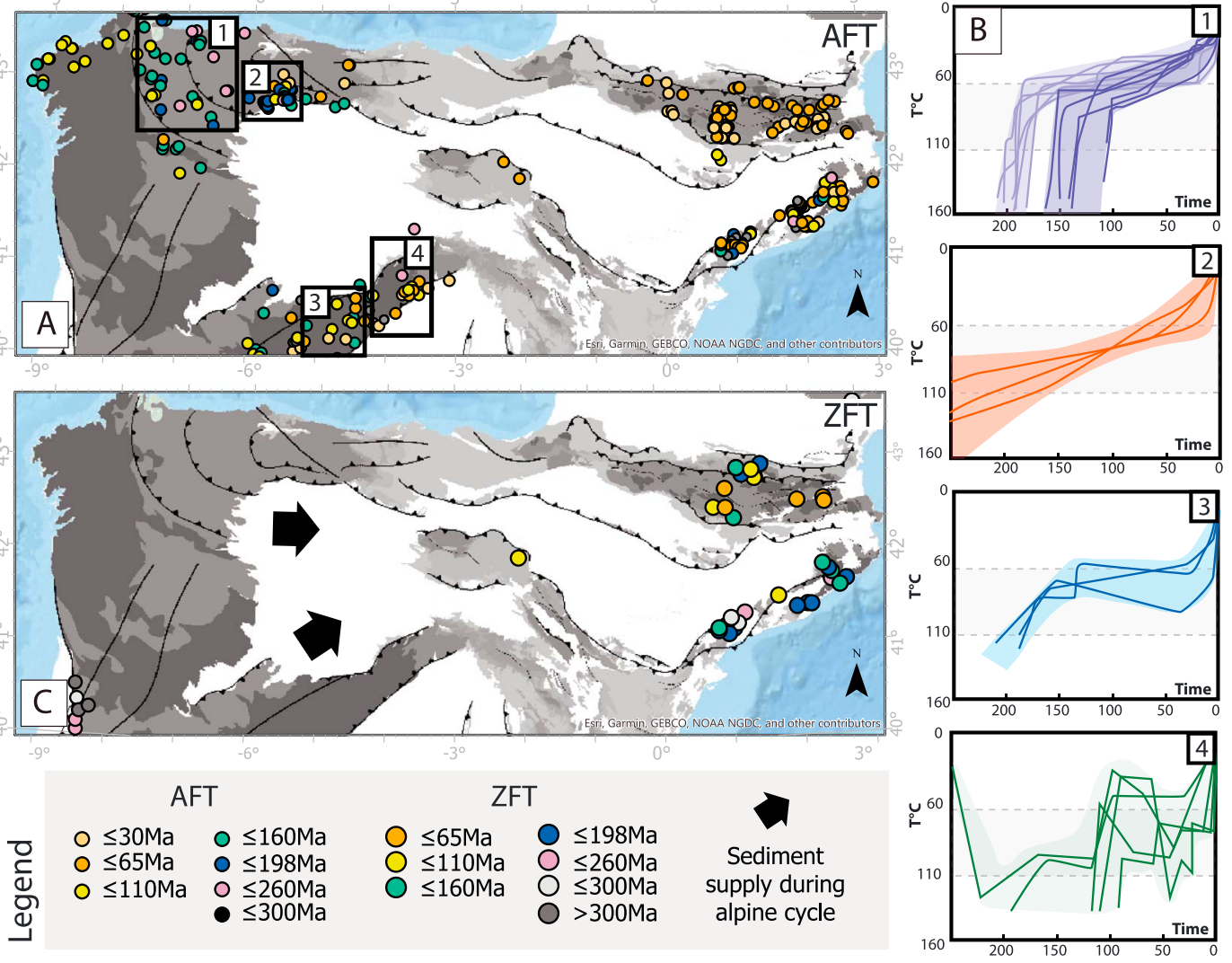

Figure 4. Existing low-temperature data sets and constraints on time-temperature evolution in northern Iberia. (a) In situ apatite fission-track (AFT) age data from Yelland (1990), Morris et al. (1998), Fitzgerald et al. (1999), Juez et Andriessen (2006), Jolivet et al. (2007), Maurel et al. (2008), Del Río, Barbero, and Stuart (2009), Grobe et al. (2010), Fillon and Van Der Beek (2012), Fillon et al. (2013, 2016), Herman et al. (2013), Botor and Anczkiewicz (2015), Bosch et al. (2016), Mouchene (2016), and Vacherat et al. (2016). In situ zircon fission-track (ZFT) age data from Maurel et al. (2008) and Sinclair et al. (2005). (c) Western Iberia thermal history $T$ - $t$ path are modified from (1) Grobe et al. (2010), (2 and 3) Bruijne and Andriesen (2002), and (4) Botor and Anczkiewicz (2015).

Table 1

Sample Description and Location (See Also Figure 2)

\begin{tabular}{|c|c|c|c|c|c|}
\hline Sample & Stratigraphic age, formation & Lithology & Latitude $\left({ }^{\circ} \mathrm{N}\right)$ & Longitude $\left({ }^{\circ} \mathrm{W}\right)$ & Altitude (m) \\
\hline CMR1 & $136 \pm 3$, Urbion & Sandstone & $42^{\circ} 10^{\prime} 57.31^{\prime \prime}$ & $2^{\circ} 20^{\prime} 22.99^{\prime \prime}$ & 925 \\
\hline CMR2 & $28 \pm 5$ & Sandstone & $42^{\circ} 14^{\prime} 42.18^{\prime \prime}$ & $2^{\circ} 7^{\prime} 26.47^{\prime \prime}$ & 738 \\
\hline CMR3 & $116 \pm 5$, Olivan & Sandstone & $42^{\circ} 16^{\prime} 14.93^{\prime \prime}$ & $2^{\circ} 17^{\prime} 35.54^{\prime \prime}$ & 730 \\
\hline CMR4 & $157 \pm 10$, Tera & Sandstone & $42^{\circ} 17^{\prime} 28.77^{\prime \prime}$ & $2^{\circ} 17^{\prime} 58.39^{\prime \prime}$ & 700 \\
\hline CMR5 & $106 \pm 5$, Utrillas & Sandstone & $42^{\circ} 11^{\prime} 22.46^{\prime \prime}$ & $2^{\circ} 12^{\prime} 5.09^{\prime \prime}$ & 936 \\
\hline CMR6 & $33 \pm 5$ & Sandstone & $42^{\circ} 12^{\prime} 15.02^{\prime \prime}$ & $2^{\circ} 12^{\prime} 12.16^{\prime \prime}$ & 682 \\
\hline CMR7 & $33 \pm 5$ & Sandstone & $42^{\circ} 12^{\prime} 49.77^{\prime \prime}$ & $2^{\circ} 11^{\prime} 7.99^{\prime \prime}$ & 676 \\
\hline CCT1 & $145 \pm 5$, Tera & Sandstone & $42^{\circ} 9^{\prime} 42.37^{\prime \prime}$ & $2^{\circ} 45^{\prime} 27.81^{\prime \prime}$ & 1,410 \\
\hline CCT4 & $145 \pm 5$, Tera & Sandstone & $42^{\circ} 7^{\prime} 55.38^{\prime \prime}$ & $2^{\circ} 59^{\prime} 18.18^{\prime \prime}$ & 952 \\
\hline CCR1 & Tera & Black shale & $42^{\circ} 10^{\prime} 20.16^{\prime \prime}$ & $2^{\circ} 42^{\prime} 18.42^{\prime \prime}$ & 1,100 \\
\hline CCR10 & Oncala & Black shale & $41^{\circ} 57^{\prime} 45.16^{\prime \prime}$ & $2^{\circ} 12^{\prime} 21.92^{\prime \prime}$ & 1,322 \\
\hline CCR11 & Oncala & Limestone & $41^{\circ} 58^{\prime} 59.01^{\prime \prime}$ & $2^{\circ} 12^{\prime} 58.84^{\prime \prime}$ & 1,240 \\
\hline CCR12 & Oncala & Limestone & $42^{\circ} 3^{\prime} 15.51^{\prime \prime}$ & $2^{\circ} 18^{\prime} 14.67^{\prime \prime}$ & 1,180 \\
\hline CCR13 & Oncala & Limestone & $42^{\circ} 4^{\prime} 10.94^{\prime \prime}$ & $2^{\circ} 19^{\prime} 37.77^{\prime \prime}$ & 1,048 \\
\hline CCR14 & Urbion & Limestone & $42^{\circ} 8^{\prime} 16.40^{\prime \prime}$ & $2^{\circ} 17^{\prime} 18.30^{\prime \prime}$ & 900 \\
\hline
\end{tabular}


Kimmeridgien-Oxfordian, Valanginian-late Aptian, and late Aptian-Early Albian deposits. We note that the depositional ages of the continental synrift sediments are based on charophites, pollens, and stratigraphic mapping (Schudack, 1987; Martín-Closas, 1989). Two sandstones (CTT1 and CCT4) were sampled at the junction between the Cameros basin and the Demanda massif in the Tera formation (145 $\pm 5 \mathrm{Ma})$, which overlies unconformably Paleozoic rocks (Figure 2a). We also sampled white sandstones CMR5 from the late to postrift Albian Utrillas Formation (106 $\pm 5 \mathrm{Ma}$ ) outcropping in the northern front of the Cameros basin. Three samples (CMR2, CMR6, and CMR7) were also collected below the northern Cameros thrust in Tertiary sediments from the Ebro basin. CMR6 and CMR7 are Late Oligocene sandstones, and CMR2 sandstone of Early Miocene ( $33 \pm 5$ and $28 \pm 5 \mathrm{Ma})$ age.

Samples for thermochronological studies were prepared at the Géosciences Environnement Toulouse Laboratory (Toulouse, Université Paul Sabatier) and at the Institut des Sciences de la Terre Laboratory (Université Grenoble Alpes). Zircon and apatite grains were separated from approximately 8-kg bulk samples using standard heavy liquid and magnetic separation from the $<500 \propto \mathrm{m}$ fraction. Zircon grains were mounted in Teflon ${ }^{\circledR}$ sheets, and apatite grains in epoxy. Spontaneous tracks were revealed by etching of polished internal grains surfaces. Zircons were etched with a NaOH-KOH melt at $228^{\circ} \mathrm{C}$ for 15 to $25 \mathrm{hr}$ using the multimount technique (Naeser et al., 1987). Apatites were etched with $5-\mathrm{M}^{\mathrm{HNO}_{3}}$ at $21{ }^{\circ} \mathrm{C}$ for $20 \mathrm{~s}$. Irradiation for both zircon and apatite samples was done at the FRM (Forschungsreaktor München) II Research Reactor at the Technische Universität München (Germany) with a nominal neutron fluence of $2.55 \times 10^{5}$ and $1.329 \times 10^{6} \mathrm{n} / \mathrm{cm}^{2}$, respectively. IRMM541 and CN5 dosimeter glasses were used to determine thermal neutron flux irradiation for zircon and apatite. Muscovite mica sheets were used for external detectors (Gleadow et al., 1976). The mica detectors were etched in $48 \% \mathrm{HF}$ (Hydrofluoric acid) at $21{ }^{\circ} \mathrm{C}$ for $18 \mathrm{~min}$ after irradiation to reveal induced tracks.

Counting of both AFT and ZFT was done at the Géosciences Environnement Toulouse Laboratory (Université Paul Sabatier) on an Olympus BX61 optical microscope with an ocular at a total 1,000X magnification and the FT-stage 4.04 software. Fission track central ages $( \pm 1 \sigma$; Galbraith \& Laslett, 1993) were measured and calculated using the zeta calibration methods with International Union of Geological Sciences age standards (Hurford \& Green, 1983). We measured horizontal confined track lengths and track etch pit size to determine the Dpar values for all apatite samples.

Apatites for AHe were handpicked in order to select inclusion-free crystal with a minimum of four replicate. Crystal dimension and geometry were measured along two axes. Equivalent spherical radius ranges from 40 to $80 \mu \mathrm{m}$. AHe analyses were carried out at the Géosciences Paris-Sud Laboratory (Université Paris-Sud). AHe ages were corrected for $\alpha$ ejection following Ketcham et al. (2011) and Gautheron et al. (2012).

For AFT sample CMR7 and zircon sample CMR4, with more than 50 grains dated and with wide grain age distributions, we decomposed the observed grain age distributions using the automatic peak fitting routine of the RadialPlotter program v. 9.4 (Galbraith \& Green, 1990; Vermeesch, 2009).

To provide better constraints on the predepositional and postdepositional thermal histories of our samples, we modeled our thermochronological data using QTQt (Gallagher, 2012; Gallagher et al., 2009) taking into account multikinetic AFT annealing and diffusion parameters for AHe.

\subsection{Thermometry and Thermobarometry: RSCM Analyses, Chlorite Thermometry, and Mica-Chlorite Thermobarometry}

To characterize peak temperature reached during Albian-Coniacian metamorphism, we performed Raman spectroscopy on carbonaceous materials (RSCM) in different stratigraphic units in the center and northern sector of the Cameros basin. CCR10, CCR11, CCR12, and CCR13 samples were collected from the Oncala Group (Barremian) of the Yanguas-Valdemadera domain (Figure 2a). Additional measurements were made outside of the main metamorphic domains. They include sample CCR14, which was collected from the Urbion limestone further north, and sample CCR1 in the Tera limestone on top of the Paleozoic rocks of the Demanda massif (Figure 2a and Table 1).

The RSCM study was used to quantify the degree of thermal transformation of carbonaceous materials. This process is an irreversible process; thus, the RSCM data represent the maximum temperature reached during metamorphism(s). RSCM analyses were performed at the BRGM (Bureau de recherches géologiques et 
minières) Orléans using the Renishaw inVia Reflex system with a light source of a 514-nm Spectra Physics argon laser.

Renishaw WiRE 3.4 was used for spectrometer calibration and Raman measurements (e.g., Delchini et al., 2016). Ten to 28 particles of carbonaceous materials were analyzed per sample. Standard errors are given for temperature with $1 \sigma$. Temperatures between 330 and $640{ }^{\circ} \mathrm{C}$ were estimated using the calibration of Beyssac et al. (2002, 2003). For lower temperatures $\left(200-330^{\circ} \mathrm{C}\right)$, we have applied the extended calibration of Lahfid et al. (2010).

Additional chlorite-mica-quartz- $\mathrm{H}_{2} \mathrm{O}$ multiequilibria thermobarometry was conducted for the CMR1 sandstone sample, which is characterized by occurrences of coprecipitated chlorite and muscovite assemblages. Quantitative analyses for mica-chlorite thermobarometry were performed at the Centre for Microanalyses Raymond Castaing (Université Paul Sabatier) using a CAMECA SXFive Electronic microprobe. The accelerating voltage was $15 \mathrm{kV}$ for a beam current of 10 or $20 \mathrm{nA}$ corresponding to an analyzed surface of $2 \times 2 \mu \mathrm{m}^{2}$. Fluorite, albite, periclase, corundum, tugtugite, sanidine, wollastonite, pyrophanite, hematite, chromium, oxide, and barite standards were used. For chlorite thermometry, we use the geothermometers proposed by Vidal et al. (2001), Bourdelle et al. (2013), and Lanari et al. (2014).

Low-grade metamorphic temperatures reached in the Cameros basin $\left(<400^{\circ} \mathrm{C}\right)$ allow us to use a multiequilibrium to determine pressure and temperature conditions during the metamorphic peak event. Phg-ChlQtz- $\mathrm{H}_{2} \mathrm{O}$ and Phg-Qtz- $\mathrm{H}_{2} \mathrm{O}$ multiequilibria were calculated with Matlab using the thermodynamic model of Vidal (2001) and Dubacq et al. (2010) and the procedure detailed in Ganne et al. (2012). In this study, we only considered the phengite-chlorite equilibrium couples with a Gibbs free energy lower than 2,400 J.

\subsection{Thermal Modeling}

To determine the thermal history of Cameros basin, we inverse modeled our multi-thermochronometer analyses using QTQt (Gallagher, 2012; Gallagher et al., 2009). The inversion procedure determines the most robust time-temperature history and kinetic parameters of low-temperature thermochronological systems that best reproduce our data, using a Bayesian Markov Chain Monte Carlo algorithm. The multicompositional annealing model of Ketcham et al. (2007) was used for AFT. QTQt implements annealing models for very low damaged zircon (Tagami et al., 1998; Yamada et al., 2007). The fanning Arrhenius model of Yamada et al. (2007) was used here for ZFT, although minor differences are observed between the two models. Because this might not be correct for old zircon grains with Paleozoic crystallization ages that are present in our study area, we have considered the temperature inferred from the earliest phases of our thermal histories with caution. QTQt also incorporates recent kinetic models for He diffusion in apatites (Flowers et al., 2009; Gautheron et al., 2009). We have tested both diffusion models for AHe and found no significant differences. We present in this study only models using the annealing model of Flowers et al. (2009).

During the inversion procedure an initial model defined by a randomly chosen time-temperature path and kinetic parameters is generated, which are compared to the input data. All the models presented in this study are based on a stable solution obtained after 1,000,000 iterations. The final model is represented by a set of time-temperature histories for which we included the expected model (weighted mean model) and the maximum likelihood model (best data fitting model). Model setups are defined by time-temperature constraints obtained from geological data such as RSCM temperatures and timing of metamorphism and current temperature at surface and at time of deposition.

\section{Results}

With this study we provide 397 new ZFT ages, 132 AFT ages, and 22 AHe ages. In addition, we bring seven new RSCM temperature and 59 chlorite temperature values. In the following, we detail our thermochronological, thermometric, and thermobarometric results that are synthesized in stratigraphic order in Tables 24 and in the supporting information (Table S1).

\subsection{ZFT, AFT, and AHe Analyses: Cameros Basin Synrift Depositional Sequence}

The ZFT analyses of sample CMR4 from the Oxfordian-early Kimmeridgian deposits yielded 97 grains with ages ranging from 62 to $394 \mathrm{Ma}$. Peak fitting reveals two age components at $91 \pm 11 \mathrm{Ma}(\mathrm{P} 1,21 \%)$ and at $165 \pm 13 \mathrm{Ma}(\mathrm{P} 2,79 \%$; Table 2). The youngest P1 population is 60-70 Myr younger than the depositional 
Table 2

Fission-Track Data

\begin{tabular}{|c|c|c|c|c|c|c|c|c|c|}
\hline $\begin{array}{l}\text { Sample } \\
\text { name }\end{array}$ & $\begin{array}{l}\text { Mineral } \\
\text { type }\end{array}$ & $\begin{array}{l}\text { Number of } \\
\text { grains }\end{array}$ & $\begin{array}{c}\rho d\left(\times 10^{6} \operatorname{tr} / \mathrm{cm}^{2}\right) \\
N d\end{array}$ & $\begin{array}{l}\mathrm{ps}\left(\times 10^{6} \mathrm{tr} / \mathrm{cm}^{2}\right) \\
\mathrm{Ns}\end{array}$ & $\begin{array}{l}\mathrm{pi}\left(\times 10^{6} \mathrm{tr} / \mathrm{cm}^{2}\right) \\
\mathrm{Ni}\end{array}$ & $\begin{array}{l}\text { Central age } \pm 1 \sigma \\
(\mathrm{Ma}) \mathrm{P}\left(\chi^{2}\right)\end{array}$ & $\begin{array}{l}\text { Age dispersion } \\
(\%)\end{array}$ & $\begin{array}{l}\text { MDpar } \pm 1 \sigma \\
(\mu \mathrm{m})\end{array}$ & $\begin{array}{l}\mathrm{MTL} \pm 1 \sigma(\mu \mathrm{m}) \\
\mathrm{Nb}\end{array}$ \\
\hline \multirow[t]{2}{*}{ CMR2 } & Apatite & 21 & 1.33 & 0.73 & 3.30 & $42.3 \pm 4.0$ & 14 & $2.12 \pm 0.4$ & $11.3 \pm 3.5$ \\
\hline & & & 13265 & 393 & 1791 & $29 \%$ & & & 5 \\
\hline \multirow[t]{2}{*}{ CMR2 } & Zircon & 53 & 0.24 & 14.4 & 1.51 & $115.8 \pm 5.9$ & 18 & - & - \\
\hline & & & 7439 & 5934 & 623 & $3.9 \%$ & & & \\
\hline \multirow[t]{2}{*}{ CMR7 } & Apatite & 52 & 1.45 & 1.51 & 4.99 & $66.8 \pm 3.8$ & 34 & $2.1 \pm 0.3$ & $11.5 \pm 2.3$ \\
\hline & & & 13265 & 2138 & 7047 & $0 \%$ & & & 90 \\
\hline \multirow[t]{2}{*}{ CMR7 } & Zircon & 57 & 0.26 & 9.61 & 0.78 & $177.6 \pm 8.1$ & 0 & - & - \\
\hline & & & 7439 & 6431 & 523 & $8 \%$ & & & \\
\hline \multirow[t]{2}{*}{ CMR6 } & Zircon & 42 & 0.26 & 8.96 & 0.79 & $161.7 \pm 9.6$ & 18 & - & - \\
\hline & & & 7439 & 4619 & 410 & $9 \%$ & & & \\
\hline \multirow[t]{2}{*}{ CMR5 } & Zircon & 48 & 0.26 & 10.2 & 1,01 & $149 \pm 8$ & 4.7 & - & - \\
\hline & & & 7439 & 4023 & 388 & $82 \%$ & & & \\
\hline \multirow[t]{2}{*}{ CMR3 } & Apatite & 20 & 1.33 & 0.96 & 5.16 & $37.2 \pm 2.1$ & 4.5 & $2.0 \pm 0.3$ & $12.2 \pm 2$ \\
\hline & & & 13265 & 383 & 2061 & $64 \%$ & & & 34 \\
\hline \multirow[t]{2}{*}{ CMR3 } & Zircon & 23 & 0.26 & 12.4 & 9.16 & $192 \pm 14$ & 0 & - & - \\
\hline & & & 7439 & 2729 & 202 & $50 \%$ & & & \\
\hline \multirow[t]{2}{*}{ CMR1 } & Apatite & 19 & 1.35 & 0.35 & 2.69 & $26.3 \pm 2.8$ & 0 & $2.65 \pm 1.3$ & $12.6 \pm 1.6$ \\
\hline & & & 13265 & 135 & 1044 & $64 \%$ & & & 10 \\
\hline \multirow[t]{2}{*}{ CMR1 } & Zircon & 79 & 0.24 & 7.02 & 1.74 & $57.8 \pm 2.4$ & 12 & - & - \\
\hline & & & 7439 & 3416 & 846 & $18 \%$ & & & \\
\hline \multirow[t]{2}{*}{ CTT4 } & Apatite & 20 & 1.18 & 0.82 & 5.3 & $27.4 \pm 1.9$ & 0.2 & $2.1 \pm 0.3$ & $12.9 \pm 2.1$ \\
\hline & & & 13086 & 236 & 1529 & $99 \%$ & & & 61 \\
\hline \multirow[t]{2}{*}{ CMR4 } & Zircon & 97 & 0.26 & 10.5 & 1.03 & $142 \pm 6.3$ & 28 & - & - \\
\hline & & & 7439 & 11145 & 1092 & $0 \%$ & & & \\
\hline
\end{tabular}

Note. Central ages were determined with the RadialPlotter program v. 9.4 (Vermeesch, 2009). MTL = mean track length (c-axis projected).

age $(157 \pm 10 \mathrm{Ma})$, indicating the zircons of this sample experienced postdepositional partial annealing. Therefore, our defined grain age peaks cannot be directly interpreted for provenance studies but provide valuable clues for the maximum temperature yielded by the Oxfordian to Kimmeridgian deposits and the timing of cooling after partial annealing.

ZFT ages of sample CMR1 collected from Valanginian deposits of the Urbion Group (Valanginian-Aptian) yielded 79 grains ranging from 24 to $137 \mathrm{Ma}$, with a central age of $57.8 \pm 2.4 \mathrm{Ma}$ (Figure 5). A large proportion of zircon grains (93\%) are younger than the depositional age (136 $\pm 3 \mathrm{Ma})$, indicating the sampled rocks reached a temperature above $250^{\circ} \mathrm{C}$. The AFT central age of this sample is $26.3 \pm 2.8 \mathrm{Ma}$. Sample CMR3 from the Olivan Group (Aptian-Early Albian) yielded only 23 ZFT ages ranging from 88 to $293 \mathrm{Ma}$, with a central age of $192.0 \pm 14 \mathrm{Ma}$, which gives some indications about the provenance of the late synrift sediments. Ninety-two percent of the grains are older than the depositional age of $116 \pm 5 \mathrm{Ma}$, indicating that CMR3 possibly experienced very moderate partial annealing after deposition. The AFT central age of this sample is $37.2 \pm 2.1 \mathrm{Ma}$. CMR5 from the Utrillas Formation (late Albian-Cenomanian) yielded 46 grains with ages ranging from 83 to $495 \mathrm{Ma}$, with a central age of $149.0 \pm 8.0 \mathrm{Ma}$. Most of the grains (90\%) are older than the depositional age. Therefore, sample CMR5 is interpreted to be only weakly partially annealed (Figure 5).

AHe single-grain analyses performed on CCT4 yielded four ages ranging from $23 \pm 3$ to $31 \pm 3 \mathrm{Ma}$, which are close to the AFT ages defined above (Table 3) and the AHe ages published by Del Río, Barbero, and Stuart (2009). CCT1, from the Tera formation, which is located at the contact between the Demanda and the Cameros basin, yielded six single-grain ages ranging from $27 \pm 2$ to $41 \pm 2 \mathrm{Ma}$ (Table 3 ). AHe ages obtained in the two samples are younger than the stratigraphic age $(145 \pm 5 \mathrm{Ma})$ and are interpreted as cooling ages.

\subsection{ZFT, AFT, and AHe Analyses: Ebro Basin Cenozoic Deposits}

ZFT analyses of CMR2, CMR6, and CMR7 samples yielded between 42 and 57 grains (Table 2 and Figure 5). They show a range of ages from 48 to $429 \mathrm{Ma}$, which are consistently older than the depositional ages, indicating no resetting after deposition (Figure 5). CMR6 and CMR7 return Jurassic ZFT central ages at 161$177 \mathrm{Ma}$, and CMR2 returns a younger Cretaceous central age of 115 Ma. AFT analyses on samples 


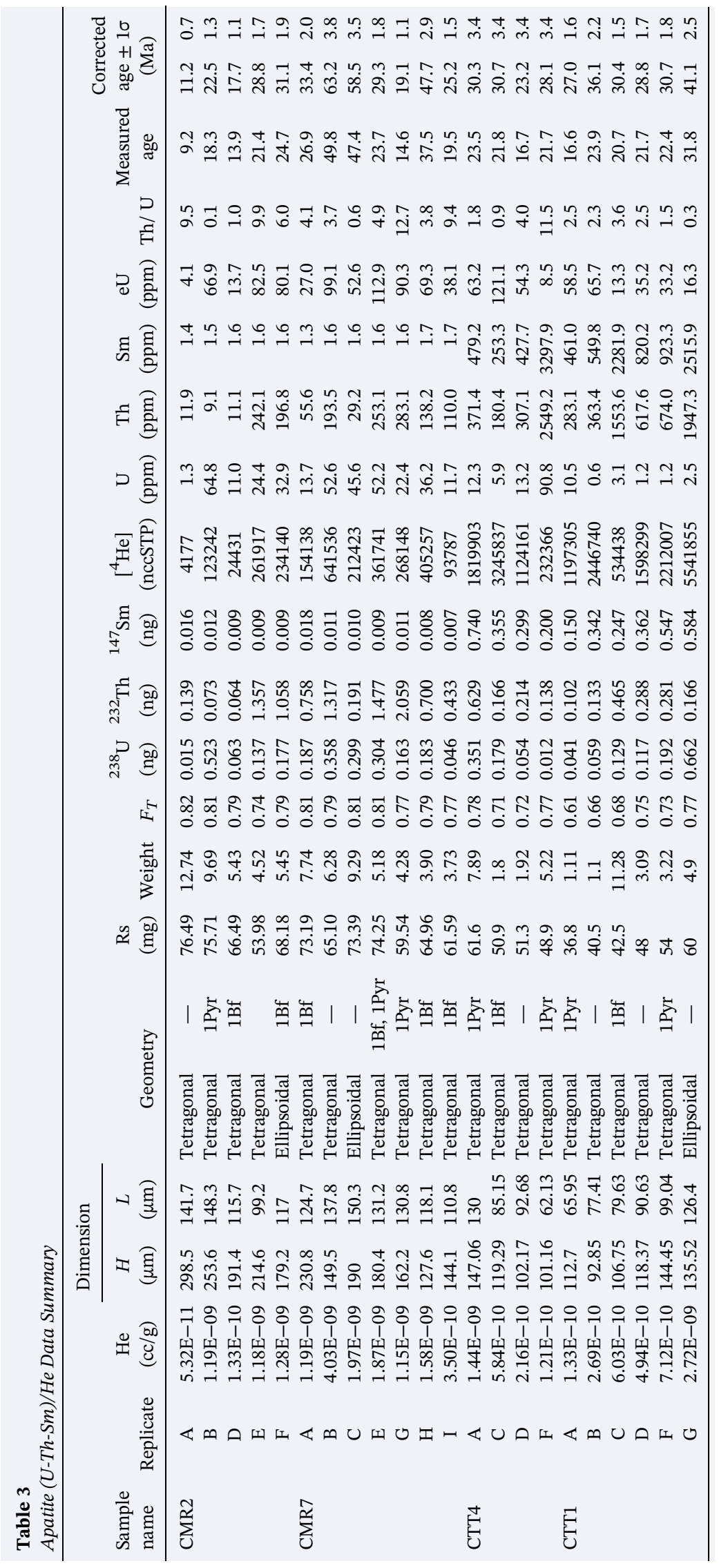


Table 4

RSCM Peak Temperatures for the Cameros Basin

\begin{tabular}{|c|c|c|c|c|c|c|c|}
\hline \multirow{2}{*}{$\begin{array}{l}\text { Sample } \\
\text { name }\end{array}$} & \multirow{2}{*}{$\begin{array}{c}\mathrm{Nb} \\
\text { spectra }\end{array}$} & \multirow[b]{2}{*}{ Method } & \multicolumn{2}{|c|}{ Raman parameter } & \multirow{2}{*}{$\begin{array}{c}T \\
\left({ }^{\circ} \mathrm{C}\right)\end{array}$} & \multirow{2}{*}{$\begin{array}{c}S D \\
\left({ }^{\circ} \mathrm{C}\right)\end{array}$} & \multirow{2}{*}{$\begin{array}{c}S E \\
\left({ }^{\circ} \mathrm{C}\right)\end{array}$} \\
\hline & & & RA1 & RA2 & & & \\
\hline CCR14 & 14 & B & & 0.56 & 393 & 28 & 9 \\
\hline CCR10 & 15 & $\mathrm{~L}$ & 0.68 & & 330 & 5 & 2 \\
\hline CCR11 & 20 & B & & 0.67 & 343 & 13 & 4 \\
\hline CCR12 & 16 & B & & 0.65 & 352 & 23 & 7 \\
\hline CCR13 & 16 & B & & 0.56 & 390 & 13 & 4 \\
\hline CCR1 & 18 & $\mathrm{~L}$ & 0.62 & & 300 & 16 & 4 \\
\hline
\end{tabular}

Note. The parameter RA1 Lahfid (Lahfid et al., 2010) and RA2 $2_{\text {Beyssac }}$ (Beyssac et al., 2002) are used to estimate temperatures $<320$ and $>330{ }^{\circ} \mathrm{C}$, respectively. Uncertainties are represented by standard errors, $S E(=1 \sigma$ standard deviation $[S D]$ divided by the square root of the number of measurements). See also Figure S2 for more details. $\mathrm{RSCM}=$ Raman spectrometry on carbonaceous materials.
CMR2 and CMR7 yielded 21 and 52 grains with ages ranging from 18 to $61 \mathrm{Ma}$ and from 24 to $216 \mathrm{Ma}$, respectively. CMR7 AFT age components recovered by peak fitting analyses show two main populations at $61.6 \pm 3.4 \mathrm{Ma}(69 \%)$ and $105.7 \pm 8.6 \mathrm{Ma}(24 \%)$, and a subordinate population at $29.0 \pm 7.4 \mathrm{Ma}(7 \%)$ is also observed. Most of the grains (93\%) are older than the depositional ages ( $33 \pm 3$ to $28 \pm 3 \mathrm{Ma}$ ), which may suggest very minor postdepositional partial resetting. Average track length measurement $(n=90)$ calculated in the sample CMR7 is $11.5 \pm 2.3$. CMR2 yielded 21 ages ranging from $18 \pm 8$ to $61 \pm 13 \mathrm{Ma}$, and with a central age at $66.8 \pm 3.8 \mathrm{Ma}$.

AHe analyses performed on CMR7 and CMR2 samples yielded seven to five grains, showing a scatter of age ranging from $19 \pm 1$ to $63 \pm 4 \mathrm{Ma}$ and from $11 \pm 1$ to $31 \pm 2 \mathrm{Ma}$, respectively. Oligocene samples systematically exhibits two to three ages younger than the stratigraphic age, which indicate a possible partial postdepositional resetting.

\subsection{Thermometry and Thermobarometry}

RSCM analyses yielded six maximum temperatures ranging from $300 \pm 16$ to $393 \pm 28{ }^{\circ} \mathrm{C}$ (Table 4; see Figure 2 for location) that are consistent considering the error associated to each measure. Maximum temperatures from the Yanguas domain vary between $330 \pm 5$ and $390 \pm 13^{\circ} \mathrm{C}$. The highest maximum temperature of $393 \pm 28^{\circ} \mathrm{C}$ is obtained outside this domain (CCR14), near the CMR1 sample location. The western border (CCR1) of the Cameros basin reveals a lower maximum temperature of $300 \pm 16{ }^{\circ} \mathrm{C}$ (Table 4 and Figure 2). Such a relatively high temperature is found at $5 \mathrm{~km}$ from the main depocenter and the metamorphic domain (see Figure 2 for sample location).

Figure 6 shows a coprecipitated mica-chlorite assemblage associated with interstitial calcite from the CMR1 quartzite. From this sample, 254 chlorite temperatures ranging from 104 to $539^{\circ} \mathrm{C}$ were obtained using the calibration of Bourdelle et al. (2013) and Lanari et al. (2014; Figure 7a). The calibration of Vidal et al. (2001) was only applied on chlorite at equilibrium condition with white mica. This thermometer yielded 59 values with temperatures ranging from 294 to $423{ }^{\circ} \mathrm{C}$. Temperature medians at 330,325 , and $350{ }^{\circ} \mathrm{C}$ from three independent thermometers (Bourdelle et al., 2013; Lanari et al., 2014; Vidal et al., 2001) are strongly consistent together (Figure 7b). Pressure-temperature hydration equilibrium conditions of the phengite-quartzwater assemblage equilibrium were obtained for CMR1 (Figure 7a). Concentration of the different equilibrium assemblages suggests a unique mica population. Pressures ranged from 0.6 to $5.5 \mathrm{kbar}$ with a median at $1.4 \mathrm{kbar}$, consistent with data obtained from the mica-quartz-water assemblage (Figure 7a). Average equilibrium assemblage suggests pressure conditions ranging from 1.1 to $1.9 \mathrm{kbar}$, temperatures between 320 and $330{ }^{\circ} \mathrm{C}$, and a water activity of $0.96-0.97$ (Figure $7 \mathrm{a}$ ). The best chlorite-phengite-quartz-water assemblage (smaller $\Delta \mathrm{G}$ ) reveals pressure and temperature conditions of $1.6 \mathrm{kbar}$ and $338^{\circ} \mathrm{C}$ (Table S3). Peak temperatures yielded by both RSCM and mica-chlorite equilibriums are consistent with greenschist metamorphism that is dated to 108 to $86 \mathrm{Ma}$ in the Cameros basin (Casquet et al., 1992).

\subsection{Thermal History of the Cameros Basin and Ebro Foreland Sediments}

Figure 8 shows model results for samples CMR1, CCT4, CMR3, and CMR2 with the fit of fission-track and AHe ages. The CMR1 Valanginian sandstones (depositional age of $137 \pm 3 \mathrm{Ma}$ ) have been heated to temperatures above $400{ }^{\circ} \mathrm{C}$ in agreement with full resetting of both AFT and ZFT ages and the occurrence of greenschist facies metamorphism. RSCM temperature estimates for sample CCR14 of the Urbion Group, located just $5 \mathrm{~km}$ to the east, confirm postdepositional heating to a maximum temperature of $398 \pm 28{ }^{\circ} \mathrm{C}$. Timing of this thermal event is constrained by Casquet et al. (1992) to have occurred in the interval between 108 (Albian) and $86 \mathrm{Ma}$ (Coniacian). Using these time-temperature constraints, we infer a phase of rapid heating of $10{ }^{\circ} \mathrm{C} / \mathrm{Myr}$ during the Early Cretaceous, followed by cooling at $70 \mathrm{Ma}$ (Figure 8). Modeling shows that a minimum temperature of $300{ }^{\circ} \mathrm{C}$ was maintained from the Albian-Coniacian thermal event to $70 \mathrm{Ma}$ (Maastrichtian).

CCT4 sandstones south of the Demanda massif show a slightly different time-temperature history. AFT and AHe analyses constrain thermal evolution below $120^{\circ} \mathrm{C}$ but lack resolution at higher temperatures. RSCM 

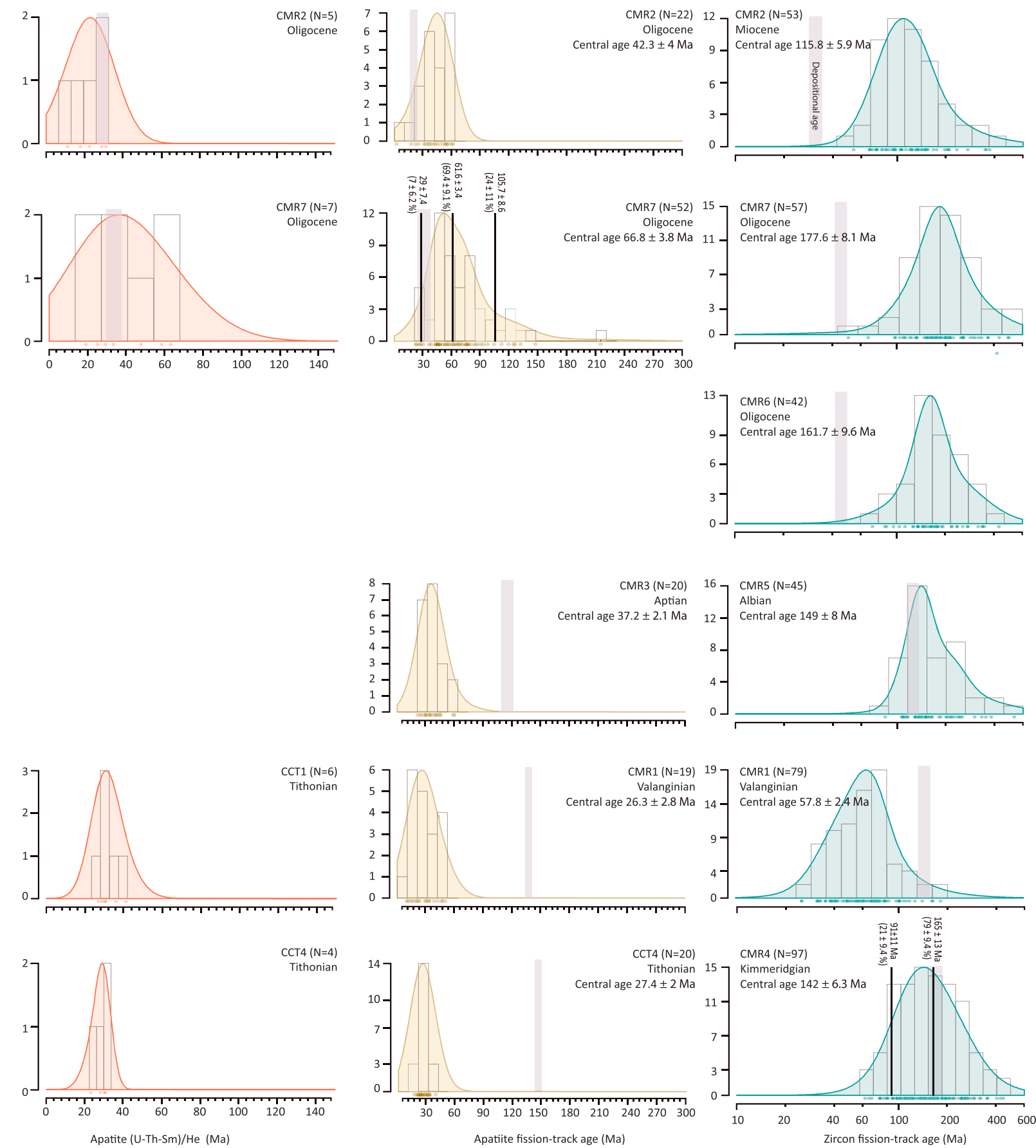

Figure 5. Fission-track kernel density plots with best fit age peaks for apatite fission-track sample CMR7 and zircon fission-track sample CMR7. Peaks were fitted using the automatic routine of the RadialPlotter program of Vermeesch (2009). Stratigraphic ages of each sample are shown as light gray bars.

data from nearby CCR1 limestones of the same Tera Group (Table 4) suggest that the Tithonian CCT4 sandstones could have reached temperatures of $300 \pm 16{ }^{\circ} \mathrm{C}$. The lack of evidence for greenschist facies metamorphism in sample CCT4 in older and presumably deeper stratigraphic position suggests that the Albian-Coniacian thermal event did not lead to characteristic mineral assemblages. This could reflect the absence of reactive fluids (and deformation?) during metamorphism.

We adopted in the modeling an RSCM temperature obtained for CCR1 that has been presumably reached during the Albian-Coniacian. Consistently with CMR1, time-temperature paths indicate CCT4 

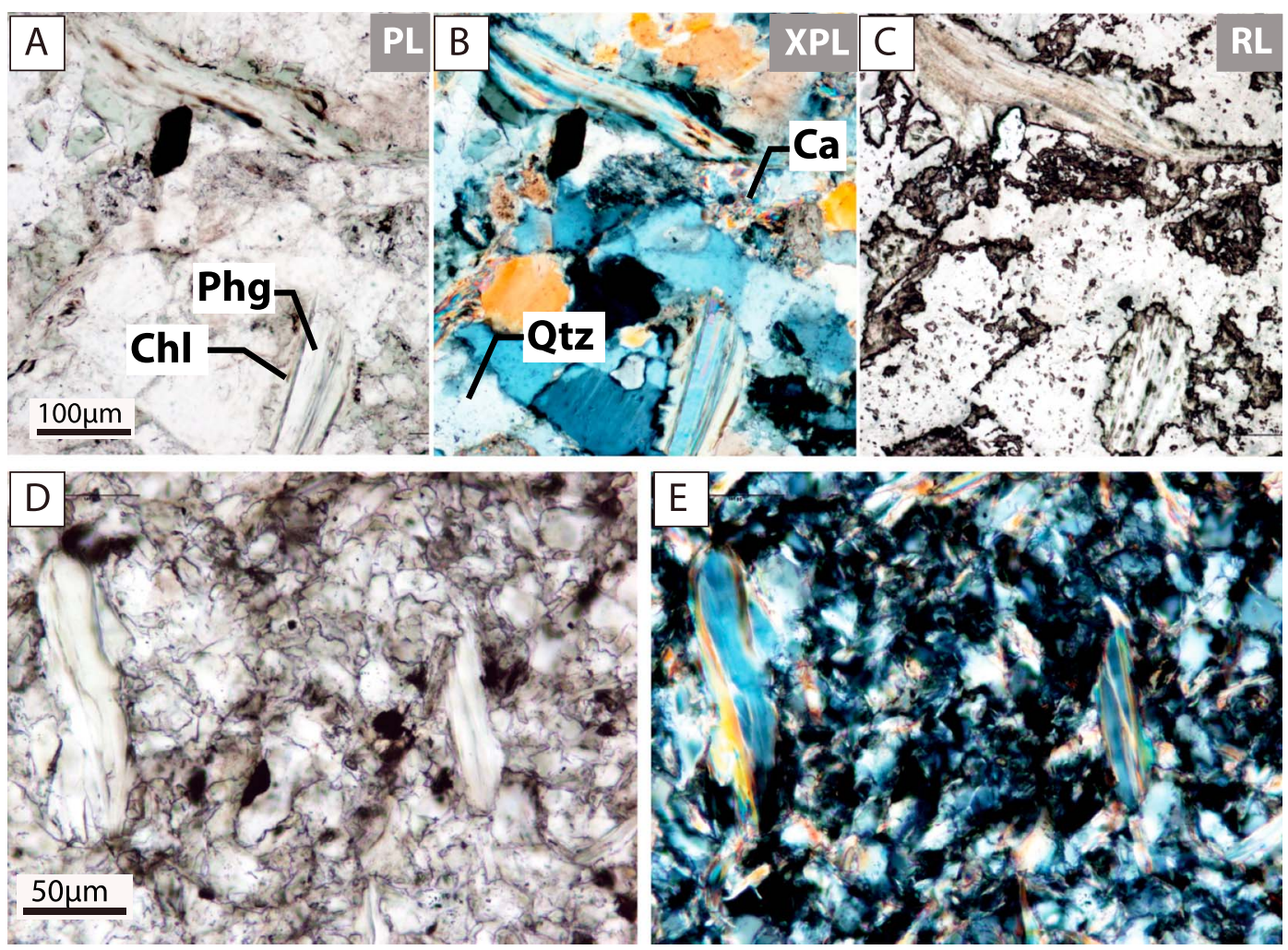

Figure 6. Thin-section pictures of mineral assemblages showing mica and chlorite crystals growing together. Chlorite (Chl), quartz (Qtz), phengite (Phg) and calcite (Ca) in CMR1 sample in (a) plane polarized light (PL), (b) cross-polarized light (XPL), and (c) reflected light (RL). Chlorite, mica, and quartz assemblage from finer fraction of CMR1 in (d) PL and (e) XPL. All the mica-chlorite couples obtained in this study originated from this finer fraction. Chlorite temperatures obtained from the different fractions are homogeneous and have similar distributions.

experienced cooling during the Late Cretaceous. From 35 to $25 \mathrm{Ma}$ (Late Eocene to Oligocene) relatively rapid cooling occurred at a rate of $7{ }^{\circ} \mathrm{C} / \mathrm{Myr}$. Since $25 \mathrm{Ma}$ (Early Miocene) onward, our sample remained close to surface temperature (Figure 8).

In contrast with models shown above, CMR3 from the Olivan Group (Aptian to Early Albian) show no clear evidence for heating above $120^{\circ} \mathrm{C}$. The Albian-Coniacian thermal event is therefore not resolved from this sample. Time-temperature paths constrain an onset of cooling at $50 \mathrm{Ma}$ (Early Eocene) at an average cooling rate of $2{ }^{\circ} \mathrm{C} / \mathrm{Ma}$ (Figure 8). This result is in agreement with a Late Cretaceous-Paleogene cooling phase in the Cameros basin, also suggested by CMR1 and CCT4 samples.

Thermal modeling of the Oligocene CMR2 sandstone sample documents postdepositional heating to a minimum temperature of $65{ }^{\circ} \mathrm{C}$ and a maximum temperature of $90{ }^{\circ} \mathrm{C}$ (Figure 8). After heating, a late cooling phase is recorded from $\sim 20 \mathrm{Ma}$ to present. The expected model shows a cooling onset at $16 \mathrm{Ma}$. Cooling occurred at rate of $8{ }^{\circ} \mathrm{C} / \mathrm{Myr}$ until $10 \mathrm{Ma}$, followed by a reduced cooling rate of $2{ }^{\circ} \mathrm{C} / \mathrm{Myr}$ from $10 \mathrm{Ma}$ to present (Figure 8). Both models suggest accelerated cooling during the Langhian, followed by a continuous cooling until present. Postdeposition heating is also suggested to minor extent by three CMR7 AHe ages at $29.3 \pm 1.8,25.2 \pm 1.5$, and $19.1 \pm 1.1 \mathrm{Ma}$, younger than the stratigraphic age (Table 3).

\section{Discussion}

\subsection{Postrift Temperature Architecture: Geometry and Possible Causes}

One of the most striking thermal features of the Cameros basin is the occurrence of greenschist metamorphism in the absence of significant overthrusting and overburden. In order to examine the relationships between the geometry of the Cameros basin and its thermal structure during the Cretaceous thermal 


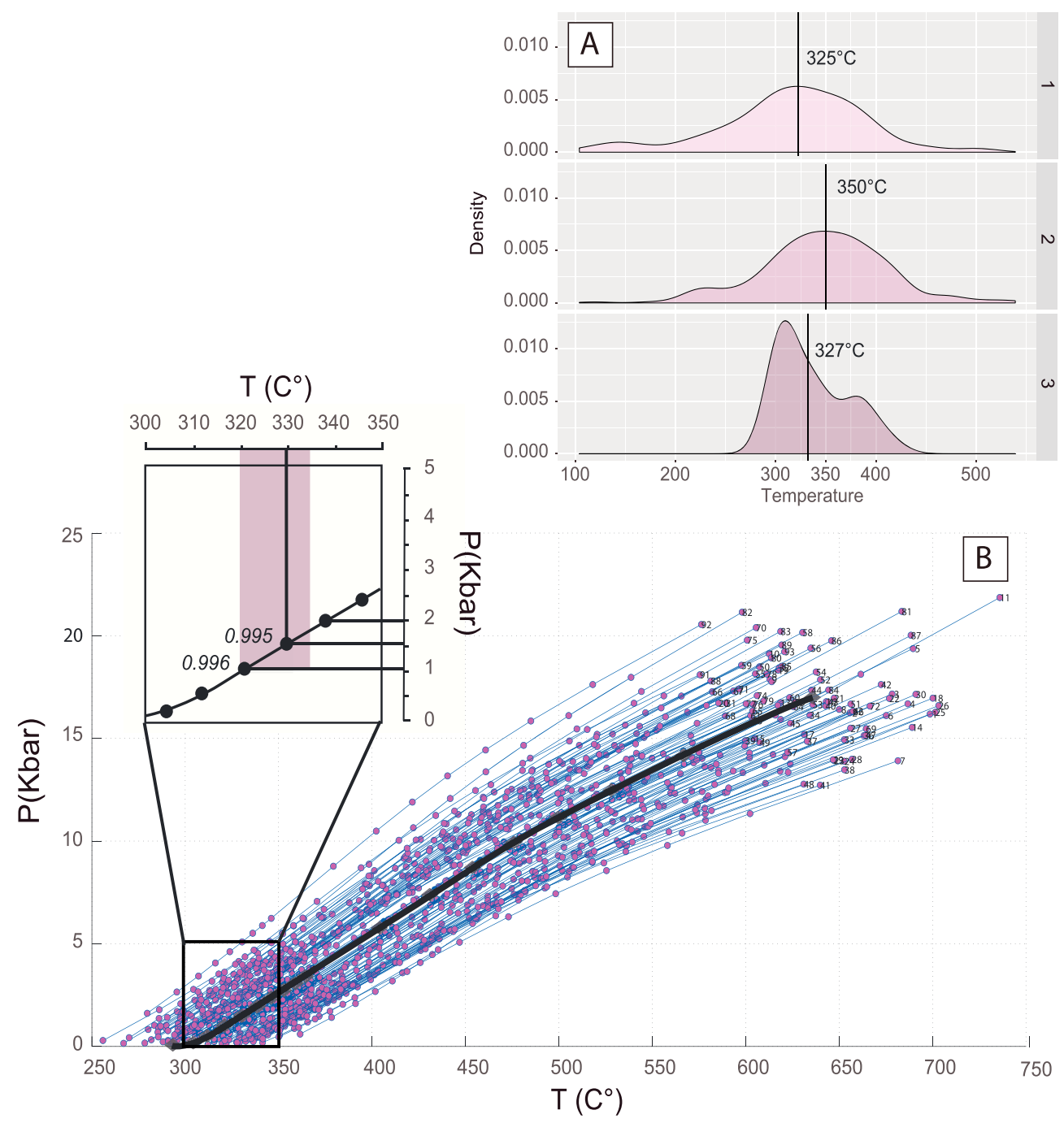

Figure 7. Thermobarometry results. (a) Temperature distributions after (1) Bourdelle et al. (2013), (2) Vidal et al. (2001), and (3) Lanari et al. (2014) thermometers. Black lines represent medians temperature for each thermometer, (b) Chl-PhgQtz- $\mathrm{H}_{2} \mathrm{O}$ equilibrium assemblage distribution after Dubacq et al. (2010) thermobarometer.

event, we exploit our low-temperature thermochronological analyses together with our new Raman temperatures and existing VR data.

A transect along samples CMR4, CMR3, and CMR1 shows an increase in temperature toward the south, independently of the samples' stratigraphic position. Early synrift deposits of the Oxfordian-early Kimmeridgian (CMR4) located in the hanging wall of the north Cameros thrust show partially reset ZFT ages $\left(T<240-300^{\circ} \mathrm{C}\right)$, while late synrift sediments of the Aptian to Early Albian Olivan Group (CMR3) show fully reset AFT and AHe ages but unreset ZFT ages $\left(110{ }^{\circ} \mathrm{C}<T<180-240{ }^{\circ} \mathrm{C}\right)$. Toward the center of the Cameros basin, Valanginian sandstones (CMR1) reveal full postdepositional annealing of fission tracks in apatite and zircon $\left(T>300{ }^{\circ} \mathrm{C}\right)$, in line with the average maximum temperature of $330{ }^{\circ} \mathrm{C}$ obtained from RSCM and chlorite thermometry. The thermal structure reflected by our data show a relationship with the increasing sedimentary thickness and/or location of greenschist metamorphism. By contrast, the lack of correlation between maximum temperatures and the stratigraphy suggests the thermal structure is inherited from precollisional stages.

Figure 9 shows a restored section of the Cameros basin during the early postrift stage (AlbianCenomanian) just after the greenschist metamorphic event (Casquet et al., 1992; Del Río, Barbero, \& Stuart, 2009). This restoration is very similar to a section proposed by Casas-Sainz and Gil-Imaz 

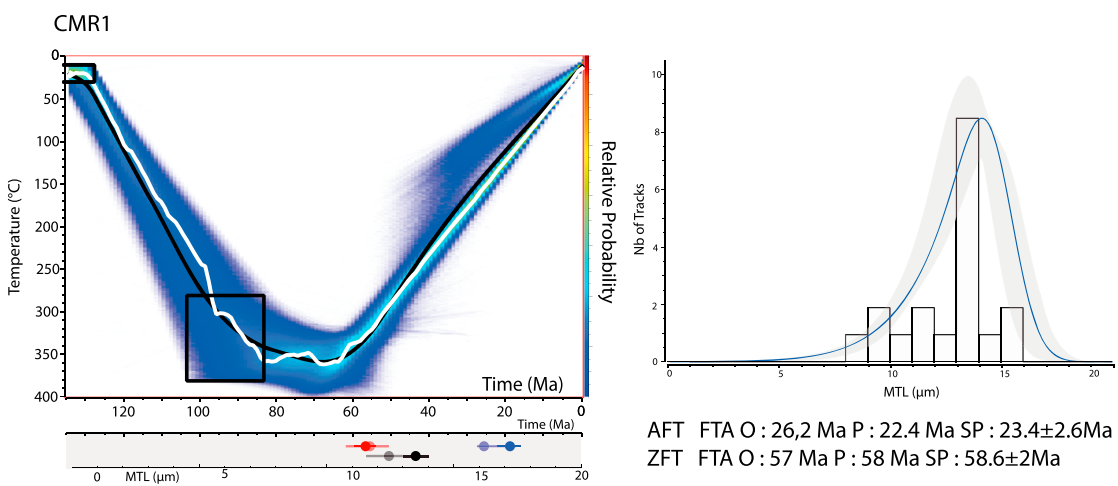

AFT FTA $0: 26,2 \mathrm{Ma} P: 22.4 \mathrm{Ma} \mathrm{SP}: 23.4 \pm 2.6 \mathrm{Ma}$ ZFT FTA O : $57 \mathrm{MaP}: 58 \mathrm{Ma} \mathrm{SP}: 58.6 \pm 2 \mathrm{Ma}$

CCT4
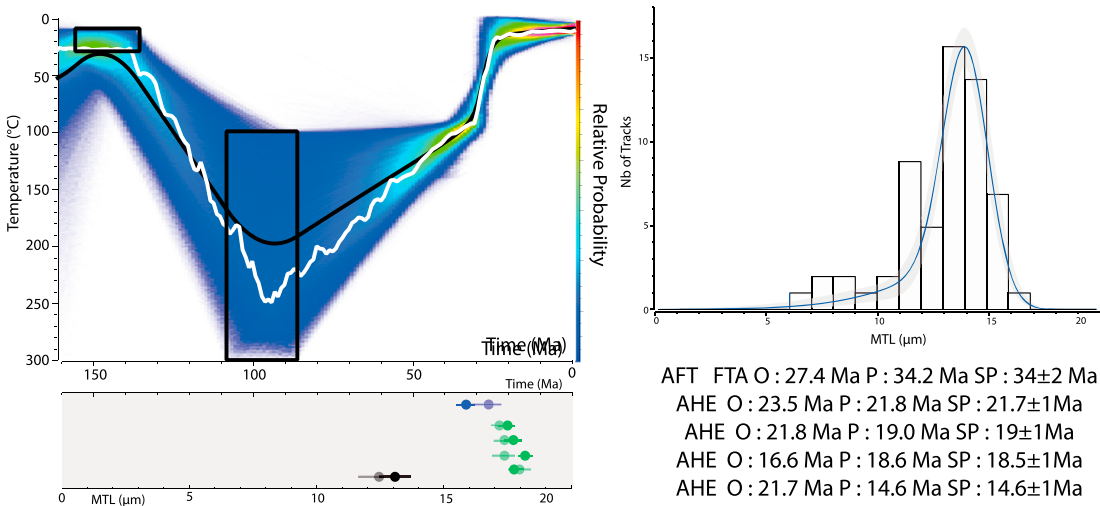

AFT FTA O : $27.4 \mathrm{Ma} P: 34.2 \mathrm{Ma} \mathrm{SP}: 34 \pm 2 \mathrm{Ma}$ AHE $0: 23.5 \mathrm{Ma} P: 21.8 \mathrm{Ma} \mathrm{SP}: 21.7 \pm 1 \mathrm{Ma}$ AHE $0: 21.8 \mathrm{Ma} P: 19.0 \mathrm{Ma}$ SP : $19 \pm 1 \mathrm{Ma}$ AHE O: $16.6 \mathrm{Ma} P: 18.6 \mathrm{MaSP}: 18.5 \pm 1 \mathrm{Ma}$ AHE $O: 21.7 \mathrm{Ma} P: 14.6 \mathrm{MaSP}: 14.6 \pm 1 \mathrm{Ma}$
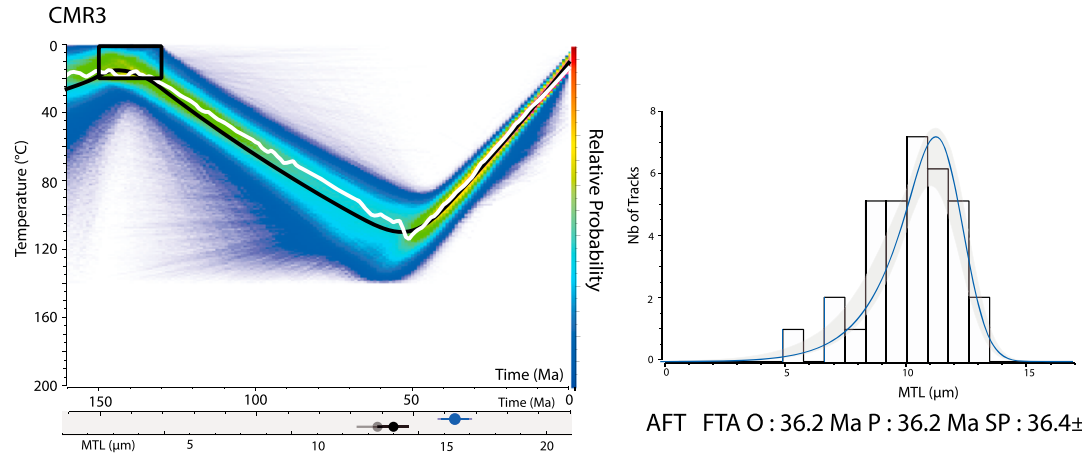

CMR2

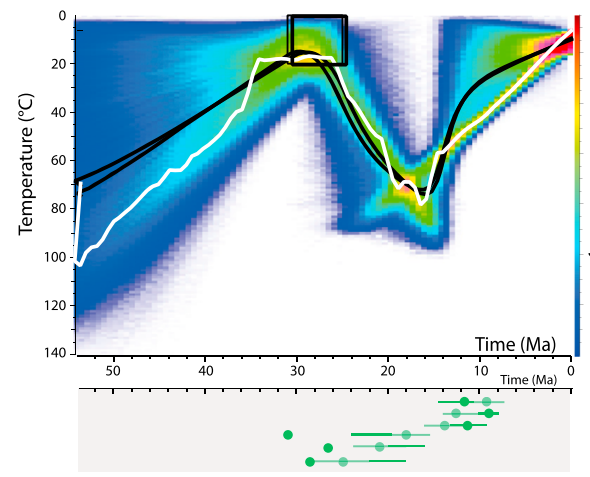

AFT FTA O : $36.2 \mathrm{Ma} P$ : $36.2 \mathrm{Ma}$ SP : 36.4+2Ma

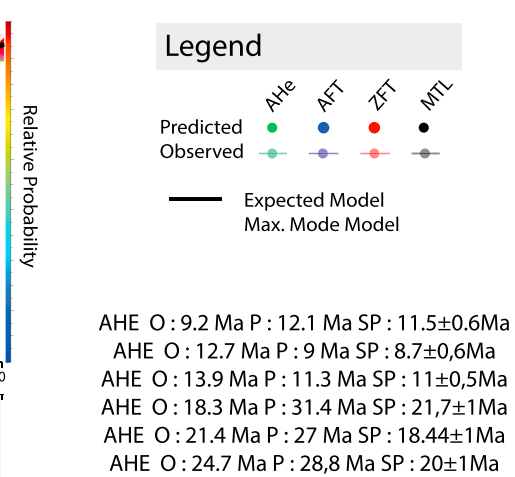

Figure 8. Thermal histories reconstructed for a selection of samples obtained using QTQt modeling approach (Gallagher, 2012). Comparison of expected versus model prediction and track-length distribution for samples CMR1, CMR3, CCT4, and CMR2 are presented. 


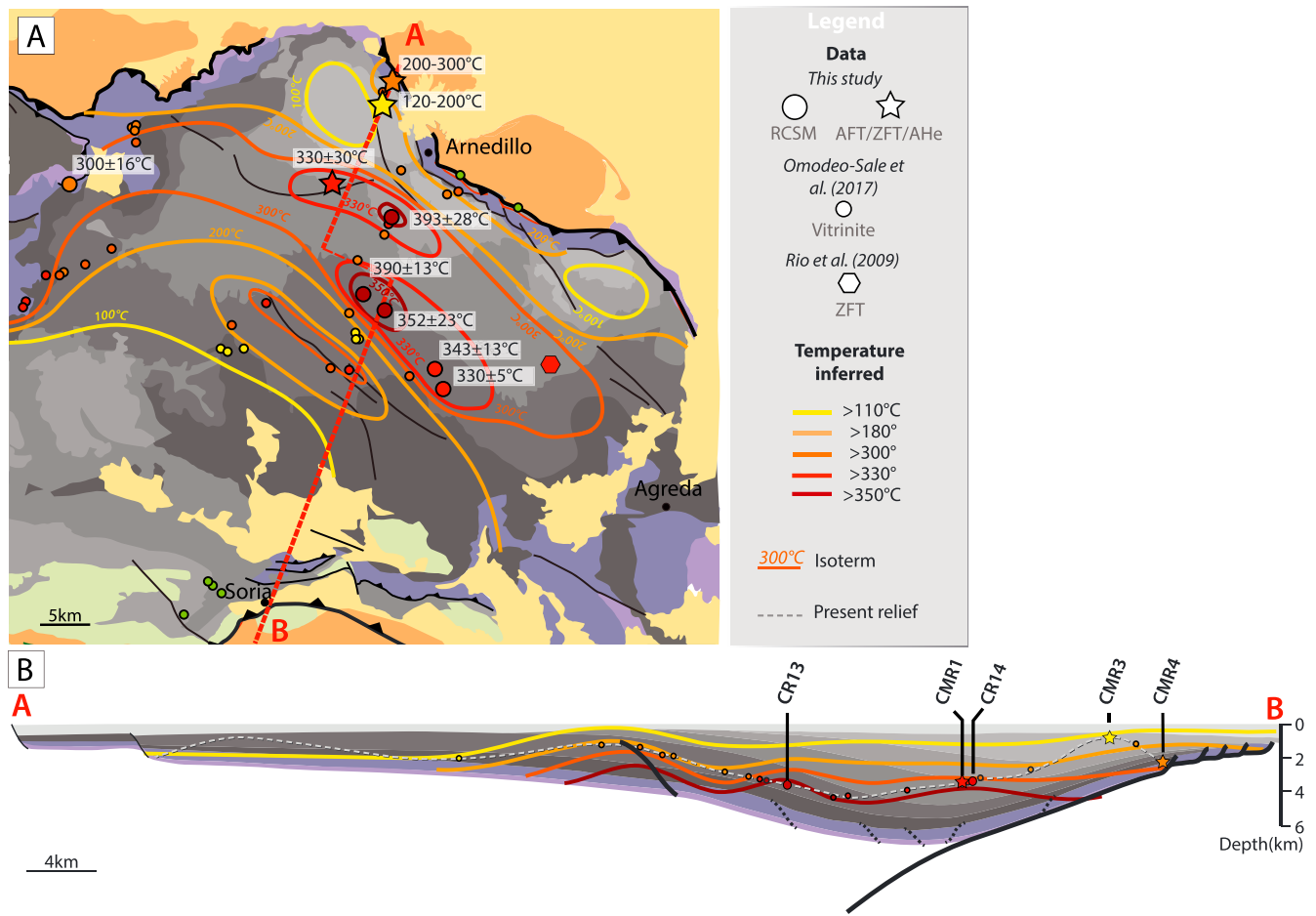

Figure 9. Spatial reconstruction of isotherms during the Albian-Coniacian. (a) Geological map of the Cameros basin with the position of the maximum temperatures inferred from different proxies. Low-temperature thermochronology was used to estimate maximum or minimum temperature limits reached during the Albian-Coniacian thermal event. Data set was completed with the reflectance vitrinite data from Omodeo-Salé et al. (2016) and with thermochronological data of Del Río, Barbero, and Stuart (2009). Temperature obtained from vitrinite are converted using the calibration of Barker and Pawlewicz (1994) for hydrothermal context (see also Table S4). (b) Restored cross-section and thermal structure during the metamorphic peak.

(1998). We have plotted on the section the original positions of our samples (CMR1, CMR3, CCR14, CCR13, and CMR4) according to the restored sediment thickness and estimated shortening. Our reconstruction estimates a maximum sediment thickness of $6.5 \mathrm{~km}$. This is lower than the maximum thickness estimated in the section of Casas-Sainz and Gil-Imaz (1998) and is explained by the difference in the strike of our section where the Olivan Group is thinner.

In addition, we have benefited from an independent estimate of the lithostatic pressure in the basin. Calculation of chlorite-phengite equilibrium allows determining a pressure of 1-1.6 kbar for CMR1 (Figure 7 and Table S1). Considering lithostatic pressure and densities of 2,700-2,500 kg/m $\mathrm{m}^{3}$ for sediments gives us a paleodepth of $3.7-4.9 \mathrm{~km}$. Combining with temperature of $338^{\circ} \mathrm{C}$, we infer a thermal gradient of $65-85{ }^{\circ} \mathrm{C} / \mathrm{km}$ (considering a surface temperature of $20^{\circ} \mathrm{C}$ ). This estimate falls in the range of previous thermal gradient estimates of $70-80^{\circ} \mathrm{C} / \mathrm{km}$ obtained by Del Río, Barbero, and Stuart (2009) and Mata et al. (2001). Based on our reconstruction, late synrift sediments (CMR3) were buried to a depth of $1.5 \mathrm{~km}$ to temperatures of $110-180{ }^{\circ} \mathrm{C}$, giving a thermal gradient of minimum $60{ }^{\circ} \mathrm{C} / \mathrm{km}$. Temperatures above $180{ }^{\circ} \mathrm{C}$ inferred from the Oxfordian-early Kimmeridgian Tera Group (CMR4) are lower than our estimate from CMR1 although it is positioned at a lower stratigraphic position. This is explained by the position of CMR4, which is located on the basin border, above the inclined extensional ramps, and therefore buried to a depth of $4 \mathrm{~km}$ only (Figure 9).

To complement our RSCM and thermochronological data sets, we have converted individual VR data from Omodeo-Salé et al. (2016) to temperatures with the calibration of Barker and Pawlewicz (1994). The use of burial calibration systematically yields lower temperatures compared to peak temperatures derived from RSCM and thermochronological data. By contrast, hydrothermal calibration shows more consistent results with our own data, especially where fluid circulation is observed (see Table S4 in depository). 
Figure 9 shows that paleo-isotherms at the Albian-Coniacian thermal event are oblique to the main fault ramp and to the dip attitudes of sedimentary layers. The highest temperatures are also not restricted to the metamorphic area of Rabanera, Yanguas-Valdemadera, and the Pegado anticline (Figures 1 and 9). This result confirms that Albian-Coniacian greenschist facies metamorphism and associated fluid flow postdate the main rifting phase in the Cameros basin. A lack of control by extensional crustal structures suggests the observed temperature gradients result from a combination of (1) thermal blanketing effect caused by low-conductivity sediments, (2) enhanced heat transfer by high-conductivity salt layers, (3) heat advection caused by depth-dependent subcrustal thinning, and (4) hydrothermal fluids.

The close temporal connection with the Albian-Cenomanian High temperature (HT) metamorphism of the north Pyrenean basin (Bernus-Maury, 1984; Clerc, 2012; Ducoux, 2017; Golberg \& Leyreloup, 1990; Lagabrielle et al., 2010) and in the Basque-Cantabrian Basin (Pedrera et al., 2017) as well as the onset of seafloor spreading in the Bay of Biscay suggests a genetic link (Figure 1b). Whereas the main cause invoked for the Pyrenean thermal event is crustal thinning and mantle exhumation (Albarède \& Michard-Vitrac, 1978; Clerc, 2012; Clerc \& Lagabrielle, 2014; de Saint Blanquat et al., 2016; Jammes et al., 2009, 2010; Lagabrielle et al., 2010; Lagabrielle \& Bodinier, 2008; Vacherat et al., 2014), in the Cameros basin, the lack of evidence for the contemporaneous thinning event supports control by large-scale subcrustal processes on the basin thermal architecture. The upwelling of the asthenosphere associated with the onset of seafloor spreading in the Bay of Biscay is a large-scale feature that may have affected the region during the Early Cretaceous. We propose that the asthenospheric flow caused by rift migration in the Pyrenees resulted in the increase of the thermal budget in the rifted basins of northern Iberia, and especially in the Cameros basin. The combination of the circulation of hot fluids along faults and permeable units (Omodeo-Salé et al., 2017) with the mobilization of high-conductivity Triassic salt and the accumulation of low-conductivity sediments prior to and during extension could have facilitated heat transfer in the Cameros basin.

\subsection{Time-Temperature Evolution From Rifting to Tectonic Inversion}

In association with the Cretaceous metamorphic event, samples CMR1, CMR3, and CCT4 recorded a phase of rapid heating at a rate of 5 to $10^{\circ} \mathrm{C} / \mathrm{Myr}$. In the deep part of the basin, CMR1 time-temperature paths show that high temperatures above $200{ }^{\circ} \mathrm{C}$ were maintained from 110 to $60 \mathrm{Ma}$. A similar timing and duration of high thermal gradient is documented in the western Pyrenean Mauleon basin (Vacherat et al., 2014). CMR1 further indicates an onset cooling phase at 70-60 Ma that is also detected by the least retentive zircons in the partially annealed CMR4 sample. In the same manner, the more retentive apatite grains, which anneal at higher temperatures, preserve a record of a Late Cretaceous cooling. Such an event is further in line with evidence of 60-Ma CMR6 and CMR2 ZFT ages and CMR7 AFT grain population in the synorogenic Ebro basin, which were probably recycled from the erosion of Cameros basin sediments (Table 2). We infer that the 70- to 60-Ma event marks the onset of tectonic inversion of the Cameros basin. It coincides well with the onset of contraction and initial cooling event in the north central Pyrenees (e.g., Mouthereau et al., 2014; Vacherat et al., 2014).

During the late Eocene to Oligocene times (35-25 Ma) a main cooling phase is documented in the Cameros basin by both AHe and AFT data (CMR3, CTT4, and CTT1 samples in Figure 8). These homogeneous AHe ages found nearby the Demanda massif and the Cameros massif could suggest that the two unities are coupled during the main contraction phase. It is also detected in Cenozoic deposits (CMR2, CMR6, and CMR7), in which the youngest AFT age population of $29 \pm 7.4$ Ma of sample CMR7 supports a main exhumation phase consistent with earlier studies in the region (e.g., Del Río, Barbero, \& Stuart, 2009; MuñozJiménez \& Casas-Sainz, 1997). Considering thermal gradients of $30^{\circ} \mathrm{C} / \mathrm{km}$ (assuming no thermal inheritance), we estimate a maximum exhumation rate of $0.33 \mathrm{~mm} /$ year (cooling rates of $10{ }^{\circ} \mathrm{C} / \mathrm{Myr}$ from CTT4), which gives a maximal total erosion of $2.3 \mathrm{~km}$ for this period.

A last exhumation phase is documented in the Ebro basin (CMR2; Figure 8) at 15 Ma after a period of postdepositional heating caused by burial below Oligo-Miocene deposits. Assuming a gradient of $30{ }^{\circ} \mathrm{C} / \mathrm{km}$, a minimum thickness of $2 \mathrm{~km}$ is estimated for Chattian to Burdigalian sediments. Such a late exhumation could be consistent with the exhumation induced by Miocene thrusting on the Cameros thrust (MuñozJiménez \& Casas-Sainz, 1997). According to the map shown in Figure 2, a post-15 Ma Miocene thrusting was probably short-lived because the Cameros thrust is sealed by the latest Miocene conglomerates (dated to 9 Ma according to Munoz-Jimenez and Casas-Sainz, 1997). This scenario is consistent with our data but 

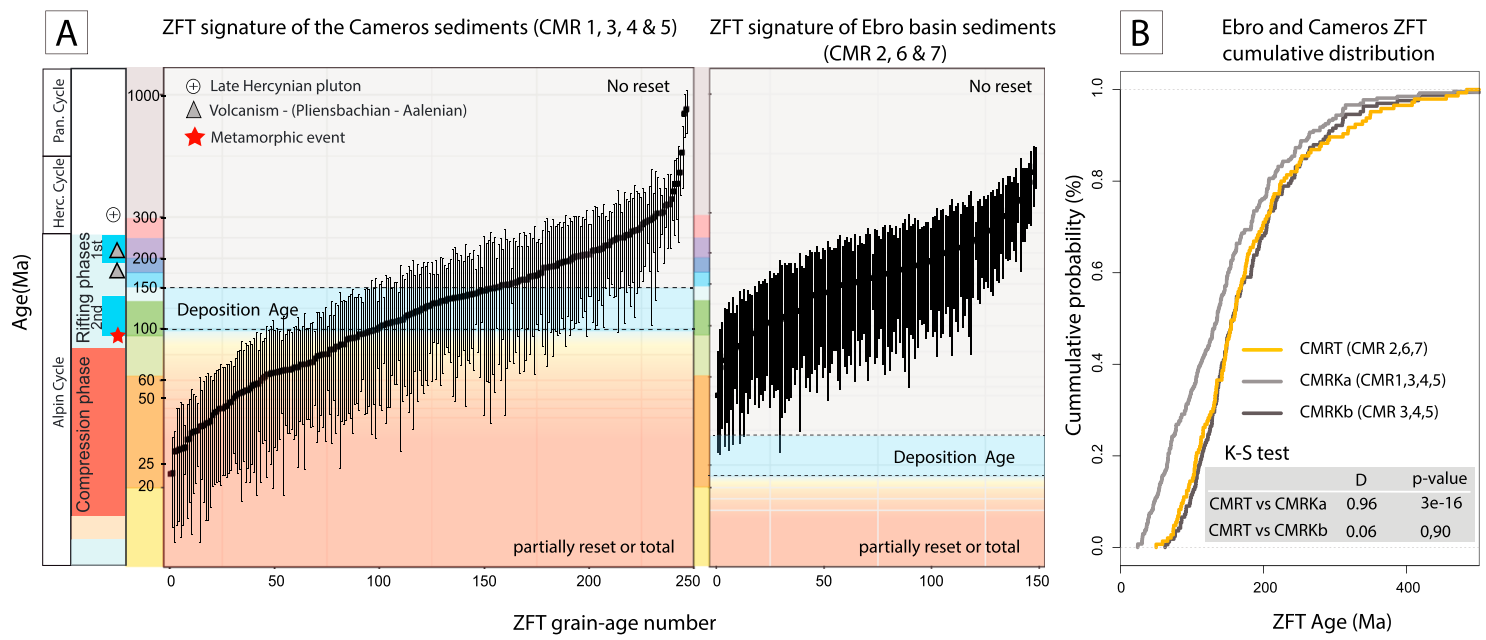

Figure 10. Zircon fission-track (ZFT) grain age cumulative distributions. (a) ZFT grain age according to grain number between the Ebro and Cameros basins. (b) Cumulative probability plot for ZFT distribution for the Ebro and Cameros sediments. The differences between the distributions of the two basins was tested using the Kolmogorov-Smirnov (KS) statistic.

cannot be resolved by thermal modeling alone, which suggests continuous cooling after 9 Ma. Additional post-9 Ma exhumation, not related to tectonics, could fit with the model results and AHe data. Altogether, our results suggest a rather slow cooling/exhumation through the AHe partial-retention zone since 9 Ma. This could fit with the large-scale postorogenic drainage reorganization in the Ebro basin inferred by Garcia-Castellanos et al. (2003) and later confirmed by thermal modeling in the southern Pyrenees (Fillon et al., 2013) at this time.

\subsection{Sediment Recycling Through the Orogenic Cycle}

Figure 10a shows the cumulative distribution of individual detrital ZFT grain ages in sediments of the Cameros basin (samples CMR1, CMR3, CMR4, and CMR5) and the Ebro foreland basin (samples CMR2, CMR6, and CMR7). They share first-order resemblance for Mesozoic and Late Paleozoic ZFT grain-age cumulative distribution (Figure 10). The young Cenozoic ZFT ages of the reset sample CMR1 are not observed in the foreland basin, indicating that sediments equivalent to CMR1 were not the source of the Oligocene-Miocene deposits. The good concordance is confirmed for Mesozoic and Late Paleozoic ZFT ages by the Kolmogorov-Smirnov test, which is used to compare the age distributions of two samples (Press et al., 1992). The distribution variation between CMRT (CMR2, CMR6, and CMR7) and CMRKb (CMR3, CMR4, and CMR5) is small relative to the variation expected by random sampling (Figure 10b). The $p$ value represents the chance that the difference between the distributions of two samples can be due to a random sampling alone. The Kolmogorov-Smirnov test shows a $p$ value of 0.9 , which reveals a probability of $90 \%$ that the variation observed might be due to a random chance alone. However, in case zircon grains from CMR1 are added to the total distribution of the Cameros samples (CMRKa), the variation observed with CMRT distribution is very high $(D=96 \%)$. The probability that this variation might be due to a random sampling only is $>5 \%$ and implies that the variation between the two distributions might not be due to a random sampling alone. This confirms that the rock sample CMR1 was not at the surface during the Oligocene to early Miocene times.

As shown in Figure 5, both Jurassic (160-180 Ma) and Early Cretaceous (90-115 Ma) ZFT ages are present in Oligocene-Miocene foreland basin deposits and the synrift sediments. Considering the large uncertainties on peak ages, the population at $116 \pm 6 \mathrm{Ma}$ (ages ranging from 58 to $333 \mathrm{Ma}$ ) found in the Cenozoic sediments is roughly concordant with reset zircon grain ages of $91 \pm 11 \mathrm{Ma}$ (ages ranging from 62 to $394 \mathrm{Ma}$ ) found in the Oxfordian to early Kimmeridgian sandstones (CMR4), which are found close to the metamorphic domains.

We deduce that the erosion of the Albian-Coniacian series in the northern Cameros thrust is probably the main source of the Oligocene-Miocene sediments in the foreland basin. The lack of ZFT age population of 
$56 \mathrm{Ma}$ from the Valanginian series (CMR1), in the Ebro basin, suggests these series were not at the surface during the Oligocene.

The Early-Middle Jurassic ZFT ages (160-190 Ma) found in the foreland basin sediments point to cooling associated with the Triassic to Middle Jurassic rifting phase in the northern Atlantic (Murillas et al., 1990; Nirrengarten et al., 2017; Rasmussen et al., 1998). They further fit with the Pliensbashian to Aalenian magmatism recorded in the Iberian Range (Martínez-González et al., 1996; Ortí \& Vaquer, 1980). Together with the fact this timing only slightly postdates Central Atlantic magmatic province magmatism at $\sim 200 \mathrm{Ma}$ (Marzoli et al., 1999), their data provide additional evidence for high thermal lithospheric conditions at the beginning of the Jurassic.

Several thermochronological studies, mainly based on AFT data, have independently documented that the basement of the West Iberia margin cooled during the Early to Middle Jurassic (Bruijne \& Andriessen, 2000, 2002; Grobe et al., 2010; Figure 4). The younging pattern of AFT ages suggests a direct relationship with crustal thinning encompassing a period of distributed deformation in an intracontinental rift system in North Atlantic, IEPB, and Ligurian Tethys. This event likely promoted denudation on the rift shoulders, thus explaining part of the Late Jurassic cooling episode. Assuming that during the Early Jurassic rocks cooled in 10 to $30 \mathrm{Myr}$ through ZFT and AFT partial annealing zones, a maximum exhumation of $7 \mathrm{~km}$ is inferred from ZFT data (assuming a normal temperature gradient of $30^{\circ} \mathrm{C} / \mathrm{km}$ and a surface temperature of $20^{\circ} \mathrm{C}$ ). Petrofacies and sedimentary studies of the second phase of rifting associated with the Late Jurassic-Early Cretaceous infill reveal source rocks located in the Iberian massifs, including the Asturian-Leonese massif in the west and the nearby Iberian central system (Arribas et al., 2003; González-Acebrón et al., 2013). Altogether, these data point to the generation of the first clastic sediments during an Early-Middle Jurassic exhumation event that were then recycled, transported, and trapped in the Cameros basin from the Late Jurassic to Early Cretaceous and ultimately recycled in the Cenozoic Ebro foreland basin.

\subsection{Placing the Cameros Basin Evolution Into the Evolution of the IEPB}

Our results allow placing constraints on the Mesozoic and Cenozoic time-temperature evolution of the Cameros basin. The results are used to propose a schematic sequential restoration of the IEPB across the Cameros basin and the western Pyrenees and examine the paleogeographic evolution of northern Iberia in general since the Late Jurassic (Figures 11 and 12).

6.4.1. Jurassic Rifting in Northern Iberia and the Cameros Basin (180-120 Ma)

The Late Triassic to the Hettangian period expresses the tentative connection between the North Atlantic domain and the Alpine Tethys domains (e.g., Salas et al., 2001). Major diachronous unconformities, subsidence partitioning, and volcanism occurred in the Early to Middle Jurassic, contemporaneous with several local extensional episodes and NW-SE fault reactivation documented from Aalenian to Bajocian (180172 Ma; Aurell, 2002; Aurell et al., 2003; Fernández López \& Gómez Fernández, 1990; García-Frank et al., 2008; Ortí \& Vaquer, 1980; Ureta, 1985). This first extension phase was followed by thermal relaxation evidenced by a slow subsidence phase, which preceded the second phase of rifting in northern Iberia during the Oxfordian to Early Cretaceous times, leading to Bay of Biscay opening in the Aptian.

During the Late Jurassic (Oxfordian)-Early Cretaceous (Barremian) times a second phase of rifting occurred. This episode corresponds to the onset of localized deformation at $145 \mathrm{Ma}$ in the North Atlantic associated with necking and hyperextension (e.g., Nirrengarten et al., 2018). It is expressed in our study area by the location of deformation on the fault-bounded domains of the Ebro block and the Iberian rift basin. The individualization of Ebro block during the Jurassic and the onset of siliciclastic influx to the Cameros basin reflect the development of NW-SE trending basins and highs (Bulard, 1972; Wilde, 1990; Figure 12). This is consistent with plate reconstructions in which the eastward motion of Iberia is accommodated by strike-slip movements along a major NW-SE trending fault zones in the Iberian Range (Nirrengarten et al., 2018).

This rifting prefigures the Bay of Biscay opening in the Aptian. As for the Columbrets basin and its equivalent, the Parentis basin, the Triassic evaporites played an important role in the accommodation of extension and the preservation of the prerift Jurassic platform (Etheve et al., 2018; Ferrer et al., 2012; Ortí et al., 2017; Suárez-González et al., 2016). From the Late Jurassic to Aptian times, extension and salt mobility in the Cameros basin allowed sliding of the prerift Jurassic carbonate rocks and reduction of evaporite thickness along the extensional ramp (Figure 11a). In addition to the thinning of the lithosphere, salt-related 
a) $150 \mathrm{Ma}$

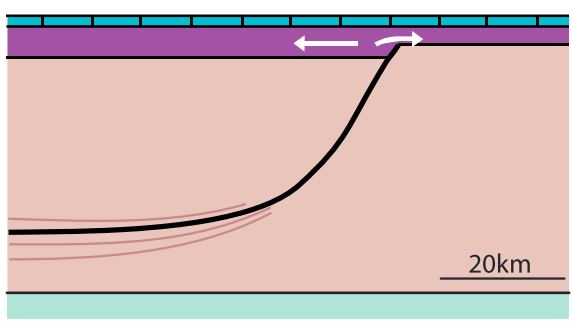

b) $115 \mathrm{Ma}$

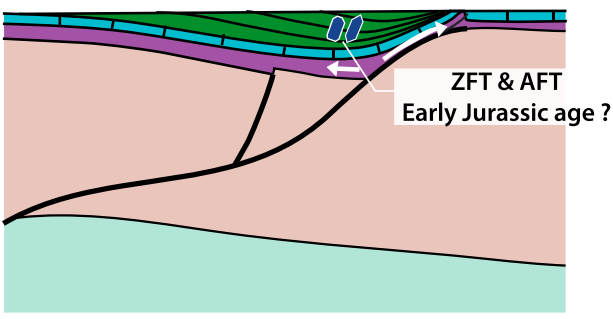

c) $100 \mathrm{Ma}$

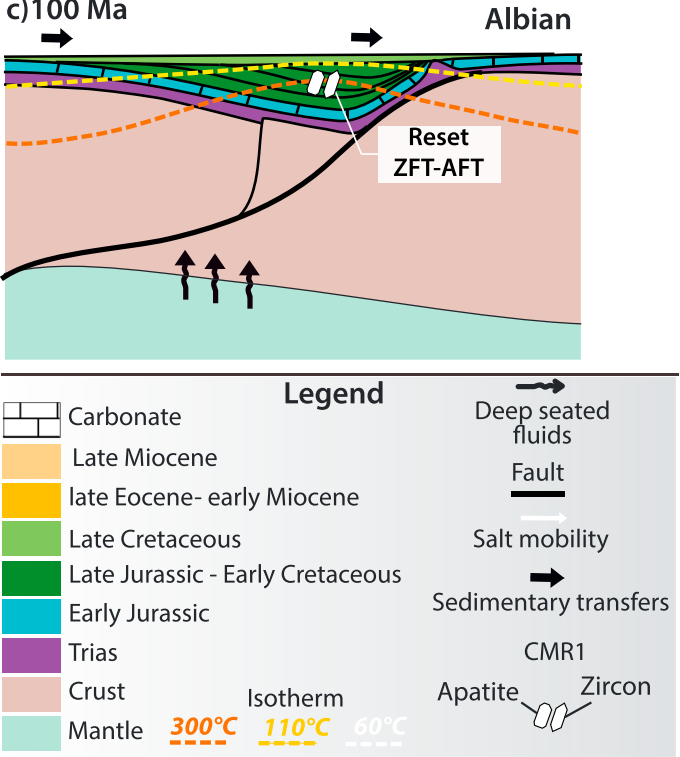

d) $60 \mathrm{Ma}$
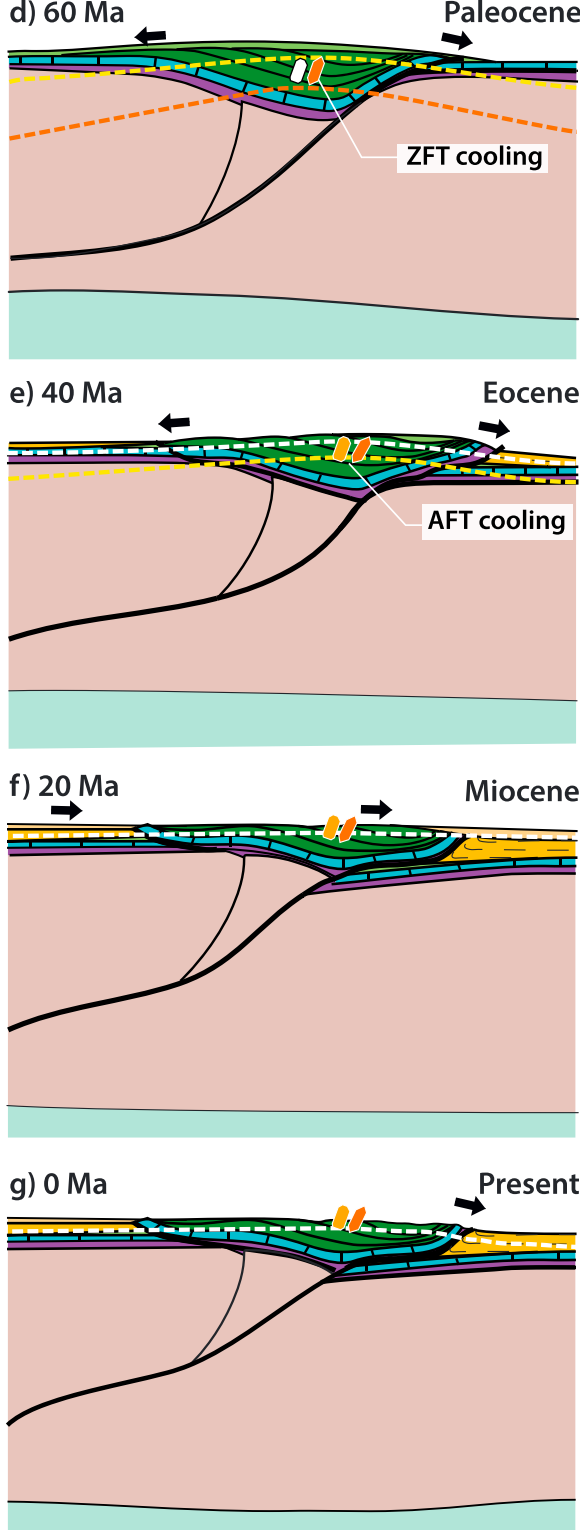

Figure 11. Schematic reconstruction of the Cameros basin exhumation from the Late Jurassic to present. (a) Onset of extension. Salt mobility allows sliding of the prerift Jurassic carbonate rocks along the extensional ramp. (b) Ongoing extension. Deposition of synrift sediments containing Early Jurassic fission-track cooling ages, supplied from the Western Iberian uplift. (c) End of extension and emplacement of mantle thermal anomaly. Note the full resetting of the CMR1, which loses its former pre-Albian cooling age signature. (d) Onset of tectonic inversion. Zircon fission-track (ZFT) grains in CMR1 cools through the $300{ }^{\circ} \mathrm{C}$ isotherm and records cooling at $\sim 55 \mathrm{Ma}$. (e) Main exhumation phase. Apatite fission-track (AFT) grains of the CMR1 sample cool below the $110^{\circ} \mathrm{C}$ isotherm recording a new cooling age at $\sim 26 \mathrm{Ma}$. (f) Ebro basin endorheic phase. CMR1 was not exposed at the surface during the Early Miocene time. (g) Current configuration of the Cameros basin.

mobility allowed the formation of synrift basin filled by erosion of the western Iberian massif to explain the occurrence of Early Jurassic fission-track cooling ages in the Cameros basin (Figure 11b).

\subsubsection{Early Cretaceous Rift Localization in the Pyrenees and Change in Thermal Structure in the} Cameros Basin (110-80 Ma)

Extension in the Cameros basin was terminated by the late Aptian to Albian. From this time onward, deformation migrated northward to the western Bay of Biscay leading to seafloor spreading. In the Pyrenees, this event is characterized by hyperextension in the continent and mantle exhumation associated to high- 


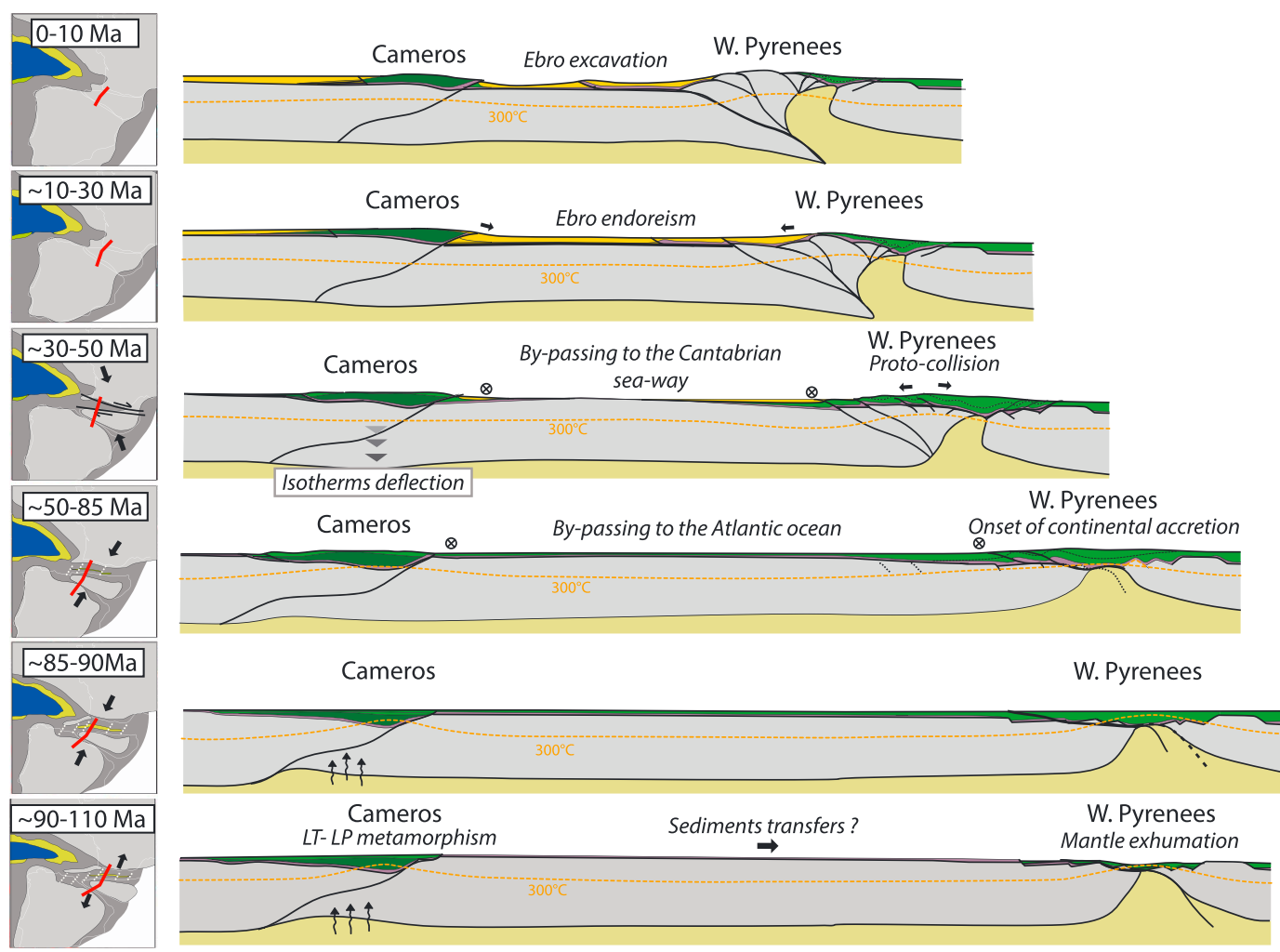

Figure 12. Schematic sequential restoration between the Cameros basin (Iberian Range) and the Mauleon basin (western Pyrenees) from the Late Jurassic to the present-day Iberia position (see text for explanation). The plate kinematic model is from Nirrengarten et al. (2017). The cross sections are striking perpendicular to the main strike-slip faults that accommodated the eastward motion of Iberia. We follow the 2-D reconstruction of Casas-Sainz and Gil-Imaz (1998), which is compatible with a transtensional evolution of the Cameros basin.

temperature low-pressure metamorphism (Figure 12). Despite the cessation of extension, both the BasqueCantabrian Basin and the Cameros basin record a contemporaneous greenschist metamorphism (DeFelipe et al., 2017). Effect of increasing temperature caused by mantle upwelling in the Bay of Biscay interacted with high-conductivity Triassic salt and low-conductivity sediments to produce hot mineralized fluids. Heating in the deepest part of Cameros caused the full resetting of the AFT and ZFT, which are processes best exemplified in the CMR1 sample, which lacks pre-Albian grain ages (Figure 11c).

This period is also characterized in northern Iberia by the widespread deposition of a thin series of shallowmarine to continental sandstones (Utrillas Formation, Escuchas Formation, or equivalent), which support the establishment of a large sediment transfer area in northern Iberia. Similar white ultramature sands of Albian depositional age are also documented in the southern Pyrenees, which strongly suggests sediment bypassing toward the northeast across the Ebro block (Figures 11 and 12; Filleaudeau, 2011; Filleaudeau et al., 2012).

\subsubsection{Onset of Tectonic Inversion and Orogenic Growth (80-37 Ma)}

Tectonic inversion began at $83 \mathrm{Ma}$ in the Pyrenees (Puigdefàbregas \& Souquet, 1986). The onset of exhumation is recorded later at 75-60 Ma in the central and eastern Pyrenees based on low-temperature thermochronology (Filleaudeau, 2011; Mouthereau et al., 2014; Rougier et al., 2016; Whitchurch et al., 2011). According to our ZFT thermochronological results, a minimum age for the inversion initiation of the Cameros basin is $\sim 60 \mathrm{Ma}$ (Figure 10d). Thermal modeling suggests long-term persistence of a rift-related high thermal gradient (Figures 11d and 12) that could mask an earlier stage of contraction not detected by low-temperature thermochronology. For instance, axial-fold cleavages documented in the eastern Cameros basin may reflect such an early contraction phase in a hot crust.

The timing of initiation of contraction and exhumation in the Cameros basin is coincident or slightly predates the widespread increase in exhumation rates during the Eocene documented in the Pyrenees (Bosch 
et al., 2016; Fitzgerald et al., 1999; Gibson et al., 2007; Gunnell et al., 2009; Herman et al., 2013; Jolivet et al., 2007; Labaume et al., 2016; Maurel et al., 2004, 2008; Metcalf et al., 2009; Morris et al., 1998; Mouchene, 2016; Rushlow et al., 2013; Sinclair et al., 2005; Vacherat et al., 2014, 2016; Whitchurch et al., 2011; Yelland, 1991). The increase of exhumation rates is interpreted to reflect the collision with a thicker and colder Iberian margin during the middle Eocene to late Eocene times (Mouthereau et al., 2014; Vacherat et al., 2016). We infer that the spatial and temporal tectonic and orogenic evolution across the IEPB from the Late Cretaceous to the Eocene was controlled by the mechanical coupling between the Pyrenees and Iberian Range in the Cameros basin (Figure 12).

6.4.4. Late Orogenic to Postorogenic Stage (37-25 Ma)

From the Paleocene to Oligocene times, the Late Cretaceous cover rocks were eroded as indicated by the absence of AFT ages older than $100 \mathrm{Ma}$ in the Oligocene Ebro basin sediments. As shown in Figure 11e, AFT grains of the CMR1 sample, previously annealed, cooled below the $110{ }^{\circ} \mathrm{C}$ isotherm, recording a late Eocene to Oligocene exhumation. This period signs a main exhumation phase in the Pyrenees, in the Cantabrian belt (Fillon et al., 2016; Fitzgerald et al., 1999), and in the Cameros basin at 35-25 Ma (Figure 8). A total exhumation of $1.5 \mathrm{~km}$ is estimated for this period in the Cameros basin. Increase in exhumation is temporally consistent with the closure of the connection of the Ebro basin with the Atlantic Ocean by $36 \mathrm{Ma}$, leading to the deposition of thick alluvial sediments (Costa et al., 2010; Puigdefàbregas et al., 1992). We note that the youngest ZFT cooling age ( $60 \mathrm{Ma})$ reported from our study is lacking in Cenozoic sediments of the Ebro basin. This implies that the deepest part of the basin was not at the surface until the Chattian (Figures 11f and 12). One kilometer of sediments was deposited in the footwall of the Cameros thrust fault between the Chattian and the Tortonian. We suggested that those late Miocene sediments could have covered part of the Cameros basin. This is supported by the occurrence of late Miocene conglomerates $(\sim 9 \mathrm{Ma})$ sealing the main Cameros thrust. Thermal modeling results and AHe data could indicate that exhumaton occurred after $\sim 9$ Ma onward, in response to drainage reorganization throughout the Ebro basin from the Tremp basin to the Cameros basin (Garcia-Castellanos et al., 2003; Fillon et al., 2013).

\section{Conclusion}

The aim of this study was to provide new insights on the tectonothermal evolution of the Cameros basin and its relationship with the regional tectonics and kinematics at the IEPB. The detrital thermochronology study combined with a multibasin approach allowed us to access the entire history of the Cameros basin (and thus northern Iberia) during almost $100 \mathrm{Myr}$ from rifting to synorogenic and postorogenic inversion.

Two rift-related thermal imprints were identified, recorded by both the synrift and postrift deposits. First, the Early to Middle Jurassic cooling event is attributed to the thermal readjustment of the lithosphere and to rift shoulder uplift of western Iberia. It corresponds probably to the attempt of a tectonic connection between the Tethys and the Atlantic Ocean in central Iberia. A new period of extension occurred in the Pyrenean rift systems during the Albian-Coniacian, which is detected in the Cameros basin as a second thermal event. Such a temporal relationship suggests thermal and mechanical coupling between the northern Iberian and Pyrenean rift systems. A minimum age for the inversion initiation of the Cameros basin is inferred at around $60 \mathrm{Ma}$, and a main exhumation phase occurred from 40 to $25 \mathrm{Ma}$. The latter exhumational cooling period is contemporaneous with the closure of the Basque-Cantabrian seaway. A late Miocene (post-15 Ma) exhumation recorded by the Ebro basin reflects displacement on the Cameros thrust. Thrusting ends before $\sim 9 \mathrm{Ma}$ as indicated by the deposition of conglomerates of that age sealing the Cameros thrust.

Acknowledgments

We gratefully acknowledge support from the Centre National de la Recherche Scientifique (CNRS), the BRGM-French Geological Survey, and TOTAL through the OROGEN project. The authors also thank Rosella Pinna Jamme for their help concerning AHe sample analyse. Data supporting Figures 5, 7, and 9 are available as Tables S1, S3, and S4. We also thank Silvia Omodeo Salé and one anonymous reviewer for their constructive reviews that greatly improved this article.
This work argues that the Iberian rift system recorded the tectonic interactions, in northern Iberia, between two rift systems identified as the Atlantic-West Tethyan rift (Early to Middle Jurassic) and the Pyrenean-Bay of Biscay rift (Early Cretaceous) at the IEPB.

\section{References}

Albarède, F., \& Michard-Vitrac, A. (1978). Age and significance of the North Pyrenean metamorphism. Earth and Planetary Science Letters, 40(3), 327-332. https://doi.org/10.1016/0012-821X(78)90157-7

Alonso, A., \& Mas, J. R. (1993). Control tectónico e influencia del eustatismo en la sedimentación del Cretácico inferior de la cuenca de Los Cameros. Cuardernos de Geología Ibéríca, 17, 285-310.

Alonso-Azcàrate, J., Barrenechea, J. F., Rodas, M., \& Mas, J. R. (1995). Comparative study of the transition between very low-grade and low-grade metamorphism in siliciclastic and carbonate sediments: Early Cretaceous, Cameros Basin (northern Spain). Clay Minerals, 30(04), 407-419. https://doi.org/10.1180/claymin.1995.030.4.12 
Arribas, J., Alonso, Á., Mas, R., Tortosa, A., Rodas, M., Barrenechea, J. F., et al. (2003). Sandstone petrography of continental depositional sequences of an intraplate rift basin: Western Cameros Basin (North Spain). Journal of Sedimentary Research, 73(2), 309-327. https://doi. org/10.1306/082602730309

Aurell, M. (2002). Jurassic. In T. Moreno \& W. Gibbons (Eds.), The Geology of Spain (1st ed., pp. 213-253). The Geological Society of London. https://doi.org/10.1144/GOSPP.11

Aurell, M., Robles, S., Bádenas, B., Rosales, I., Quesada, S., Meléndez, G., \& García-Ramos, J. C. (2003). Transgressive-regressive cycles and Jurassic palaeogeography of northeast Iberia. Sedimentary Geology, 162(3-4), 239-271. https://doi.org/10.1016/S0037-0738(03)00154-4

Barker, C. E., \& Pawlewicz, M. J. (1994). Calculation of vitrinite reflectance from thermal histories and peak temperatures: A comparison of methods. In P. K. Mukhopadhyay \& W. G. Dow (Eds.), Vitrinite reflectance as a maturity parameter (Vol. 570, pp. 216-229). Washington, DC: American Chemical Society. https://doi.org/10.1021/bk-1994-0570.ch014

Barnett-Moore, N., Hosseinpour, M., \& Maus, S. (2016). Assessing discrepancies between previous plate kinematic models of Mesozoic Iberia and their constraints. Tectonics, 35, 1843-1862. https://doi.org/10.1002/2015TC004019

Barrenechea, J. F., Rodas, M., Frey, M., Alonso-Azcárate, J., \& Mas, J. R. (2001). Clay diagenesis and low-grade metamorphism of Tithonian and Berriasian sediments in the Cameros Basin (Spain). Clay Minerals, 36(03), 325-333. https://doi.org/10.1180/000985501750539427

Bernus-Maury, C. (1984). Etude des paragèneses caractéristiques du métamorphisme mésozoique dans la partie orientale des Pyrénées. Paris.

Beuther, A. (1966). Geologische untersuchunger in Wealden und Utrillasschiten im westteil der Sierra de los Cameros. Beihefte Zum Gelogis-Chen Jahrbuch Hannover, 44, 103-121.

Beyssac, O., Goffé, B., Chopin, C., \& Rouzaud, J. N. (2002). Raman spectra of carbonaceous material in metasediments: A new geothermometer. Journal of Metamorphic Geology, 20(9), 859-871. https://doi.org/10.1046/j.1525-1314.2002.00408.x

Beyssac, O., Goffé, B., Petitet, J.-P., Froigneux, E., Moreau, M., \& Rouzaud, J.-N. (2003). On the characterization of disordered and heterogeneous carbonaceous materials by Raman spectroscopy. Spectrochimica Acta Part A: Molecular and Biomolecular Spectroscopy, 59(10), 2267-2276. https://doi.org/10.1016/S1386-1425(03)00070-2

Bosch, G., Teixell, A., Jolivet, M., Labaume, P., Stockli, D., Domènech, M., \& Monié, P. (2016). Timing of Eocene-Miocene thrust activity in the Western Axial Zone and Chaînons Béarnais (west-central Pyrenees) revealed by multi-method thermochronology. Comptes Rendus Geoscience, 348(3-4), 246-256. https://doi.org/10.1016/j.crte.2016.01.001

Botor, D., \& Anczkiewicz, A. A. (2015). Thermal history of the Sabero Coalfield (Southern Cantabrian Zone, NW Spain) as revealed by apatite fission track analyses from tonstein horizons: Implications for timing of coalification. International Journal of Earth Sciences, 104(7), 1779-1793. https://doi.org/10.1007/s00531-015-1169-z

Bourdelle, F., Parra, T., Chopin, C., \& Beyssac, O. (2013). A new chlorite geothermometer for diagenetic to low-grade metamorphic conditions. Contributions to Mineralogy and Petrology, 165(4), 723-735. https://doi.org/10.1007/s00410-012-0832-7

Bruijne, C. H., \& Andriessen, P. (2000). Interplay of intraplate tectonics and surface processes in the Sierra de Guadarrama (central Spain) assessed by apatite fission track analysis. Physics and Chemistry of the Earth, 25(6-7), 555-563. https://doi.org/10.1016/S14641895(00)00085-5

Bruijne, C. H., \& Andriessen, P. A. M. (2002). Far field effects of Alpine plate tectonism in the Iberian microplate recorded by fault-related denudation in the Spanish Central System. Tectonophysics, 349(1-4), 161-184. https://doi.org/10.1016/S0040-1951(02)00052-5

Bulard, P.-F. (1972, January 1). Le Jurassique moyen et supérieur de la Chaîne Ibérique sur la bordure du bassin de l'Ebre (Espagne). Université de Nice.

Casas, A. M., Casas, A., Pérez, A., Tena, S., Barrier, L., Gapais, D., \& Nalpas, T. (2000). Syn-tectonic sedimentation and thrust-and-fold kinematics at the intra-mountain Montalbán Basin (northern Iberian chain, Spain). Geodinamica Acta, 13(1), 1-17. https://doi.org/ 10.1016/S0985-3111(00)00105-4

Casas, A. M., Villalaín, J. J., Soto, R., Gil-Imaz, A., del Río, P., \& Fernández, G. (2009). Multidisciplinary approach to an extensional syncline model for the Mesozoic Cameros Basin (N Spain). Tectonophysics, 470(1-2), 3-20. https://doi.org/10.1016/j.tecto.2008.04.020

Casas Sainz, A. M. (1993). Oblique tectonic inversion and basement thrusting in the Cameros massif (northern Spain). Geodinamica Acta, 6(3), 202-216. https://doi.org/10.1080/09853111.1993.11105248

Casas-Sainz, A. M., \& Gil-Imaz, A. (1998). Extensional subsidence, contractional folding and thrust inversion of the eastern Cameros Basin, northern Spain. Geologische Rundschau, 86(4), 802-818. https://doi.org/10.1007/s005310050178

Casas-Sainz, A. M., \& Simón-Gómez, J. (1992). Stress field and thrust kinematics: A model for the tectonic inversion of the cameros massif (Spain). Journal of Structural Geology, 14(5), 521-530. https://doi.org/10.1016/0191-8141(92)90154-O

Casquet, C., Galindo Francisco, M., González Casado, J. M., \& Alonso Millán, Á. (1992). El metamorfismo en la cuenca de los Cameros. Geocronología e implicaciones tectónicas. Geogaceta, 11, 22-25.

Clerc, C. (2012). Évolution du domaine nord-Pyrénéen au crétacé. Amincissement crustal extrême et thermicité élevée-Un analogue pour les marges passives. Université Pierre et Marie Curie - Paris VI

Clerc, C., \& Lagabrielle, Y. (2014). Thermal control on the modes of crustal thinning leading to mantle exhumation: Insights from the Cretaceous Pyrenean hot paleomargins. Tectonics, 33, 1340-1359. https://doi.org/10.1002/2013TC003471

Clerc, C., Lahfid, A., Monié, P., Lagabrielle, Y., Chopin, C., Poujol, M., et al. (2015). High-temperature metamorphism during extreme thinning of the continental crust: A reappraisal of the North Pyrenean passive paleomargin. Solid Earth, 6(2), 643-668. https://doi.org/ $10.5194 / \mathrm{se}-6-643-2015$

Costa, E., Garcés, M., López-Blanco, M., Beamud, E., Gómez-Paccard, M., \& Larrasoaña, J. C. (2010). Closing and continentalization of the South Pyrenean foreland basin (NE Spain): Magnetochronological constraints. Basin Research, 22(6), 904-917. https://doi.org/10.1111/ j.1365-2117.2009.00452.x

de Saint Blanquat, M., Bajolet, F., Grand'Homme, A., Proietti, A., Zanti, M., Boutin, A., et al. (2016). Cretaceous mantle exhumation in the Central Pyrenees: New constraints from the peridotites in eastern Ariège (North Pyrenean zone, France). Comptes Rendus Geoscience, 348(3-4), 268-278. https://doi.org/10.1016/j.crte.2015.12.003

DeFelipe, I., Pedreira, D., Pulgar, J. A., Iriarte, E., \& Mendia, M. (2017). Mantle exhumation and metamorphism in the Basque-Cantabrian Basin (N Spain): Stable and clumped isotope analysis in carbonates and comparison with ophicalcites in the North-Pyrenean Zone (Urdach and Lherz). Geochemistry, Geophysics, Geosystems, 18, 631-652. https://doi.org/10.1002/2016GC006690

Del Río, P., Barbero, L., Mata, P., \& Fanning, C. M. (2009). Timing of diagenesis and very low-grade metamorphism in the eastern sector of the Sierra de Cameros (Iberian Range, Spain): A U/Pb SHRIMP study on monazite. Terra Nova, 21(6), 438-445. https://doi.org/10.1111/ j.1365-3121.2009.00900.x

Del Río, P., Barbero, L., \& Stuart, F. M. (2009). Exhumation of the Sierra de Cameros (Iberian Range, Spain): Constraints from lowtemperature thermochronology. Geological Society, London, Special Publications, 324(1), 153-166. https://doi.org/10.1144/SP324.12 
Delchini, S., Lahfid, A., Plunder, A., \& Michard, A. (2016). Applicability of the RSCM geothermometry approach in a complex tectonometamorphic context: The Jebilet massif case study (Variscan Belt, Morocco). Lithos, 256-257, 1-12. https://doi.org/10.1016/j. lithos.2016.04.007

Díaz, J., \& Gallart, J. (2009). Crustal structure beneath the Iberian Peninsula and surrounding waters: A new compilation of deep seismic sounding results. Physics of the Earth and Planetary Interiors, 173(1-2), 181-190. https://doi.org/10.1016/j.pepi.2008.11.008

Dubacq, B., Vidal, O., \& De Andrade, V. (2010). Dehydration of dioctahedral aluminous phyllosilicates: Thermodynamic modelling and implications for thermobarometric estimates. Contributions to Mineralogy and Petrology, 159(2), 159-174. https://doi.org/10.1007/ s00410-009-0421-6

Ducoux, M. (2017). Structure, thermicité et évolution géodynamique de la Zone Interne Métamorphique des Pyrénée. Orléans.

Etheve, N., Mohn, G., Frizon de Lamotte, D., Roca, E., Tugend, J., \& Gómez-Romeu, J. (2018). Extreme Mesozoic crustal thinning in the Eastern Iberia margin: The example of the Columbrets Basin (Valencia Trough). Tectonics, 37, 636-662. https://doi.org/10.1002/ 2017 TC004613

Fernández López, S. R., \& Gómez Fernández, J. J. (1990). Facies aalenienses y bajocienses con evidencias de emersión y carstifcatión. Cuadernos de Geología Ibérica, 14, 67-111.

Ferrer, O., Jackson, M. P. A., Roca, E., \& Rubinat, M. (2012). Evolution of salt structures during extension and inversion of the Offshore Parentis Basin (Eastern Bay of Biscay). Geological Society, London, Special Publications, 363(1), 361-380. https://doi.org/10.1144/ SP363.16

Filleaudeau, P.-Y. (2011). Croissance et dénudation des Pyrénées du Crétacé supérieur au Paléogène: apports de l'analyse de bassin et thermochronométrie détritique (Sciences de la Terre). Université Pierre et Marie Curie-Paris VI.

Filleaudeau, P.-Y., Mouthereau, F., \& Pik, R. (2012). Thermo-tectonic evolution of the south-central Pyrenees from rifting to orogeny: Insights from detrital zircon $\mathrm{U} / \mathrm{Pb}$ and (U-Th)/He thermochronometry. Basin Research, 24(4), 401-417. https://doi.org/10.1111/j.13652117.2011.00535.x

Fillon, C., Pedreira, D., Van Der Beek, P., Huismans, R. S., Barbero, L., \& Pulgar, J. A. (2016). Alpine exhumation of the central Cantabrian Mountains, northwest Spain. Tectonics, 35, 339-356. https://doi.org/10.1002/2015TC004050

Fillon, C., \& Van Der Beek, P. (2012). Post-orogenic evolution of the southern Pyrenees: Constraints from inverse thermo-kinematic modelling of low-temperature thermochronology data. Basin Research, 24(4), 418-436. https://doi.org/10.1111/j.1365-2117.2011.00533.x

Fillon, C., Gautheron, C., \& Van Der Beek, P. (2013). Oligocene-Miocene burial and exhumation of the Southern Pyrenean foreland quantified by low-temperature thermochronology. Journal of the Geological Society, London, 107, 67-77. https://doi.org/10.1144/jgs2012-051

Fitzgerald, P., Muñoz, J., Coney, P., \& Baldwin, S. (1999). Asymmetric exhumation across the Pyrenean orogen: Implications for the tectonic evolution of a collisional orogen. Earth and Planetary Science Letters, 173(3), 157-170. https://doi.org/10.1016/S0012$821 X(99) 00225-3$

Flowers, R. M., Ketcham, R. A., Shuster, D. L., \& Farley, K. A. (2009). Apatite (U-Th)/He thermochronometry using a radiation damage accumulation and annealing model. Geochimica et Cosmochimica Acta, 73(8), 2347-2365. https://doi.org/10.1016/j.gca.2009.01.015

Galbraith, R. F., \& Green, P. F. (1990). Estimating the component ages in a finite mixture. International Journal of Radiation Applications and Instrumentation. Part D. Nuclear Tracks and Radiation Measurements, 17(3), 197-206. https://doi.org/10.1016/13590189(90)90035-V

Galbraith, R. F., \& Laslett, G. M. (1993). Statistical models for mixed fission track ages. Nuclear Tracks and Radiation Measurements, 21(4), 459-470. https://doi.org/10.1016/1359-0189(93)90185-C

Gallagher, K. (2012). Transdimensional inverse thermal history modeling for quantitative thermochronology: Transdimenqional inverse thermal history. Journal of Geophysical Research, 117, B02408. https://doi.org/10.1029/2011JB008825

Gallagher, K., Charvin, K., Nielsen, S., Sambridge, M., \& Stephenson, J. (2009). Markov chain Monte Carlo (MCMC) sampling methods to determine optimal models, model resolution and model choice for Earth science problems. Marine and Petroleum Geology, 26(4), 525-535. https://doi.org/10.1016/j.marpetgeo.2009.01.003

Ganne, J., Andrade, V. D., Weinberg, R. F., Vidal, O., Dubacq, B., Kagambega, N., et al. (2012). Modern-style plate subduction preserved in the Palaeoproterozoic West African craton. Nature Geoscience, 5(1), 60-65. https://doi.org/10.1038/ngeo1321

Garcia-Castellanos, D., Vergés, J., Gaspar-Escribano, J., \& Cloetingh, S. (2003). Interplay between tectonics, climate, and fluvial transport during the Cenozoic evolution of the Ebro Basin (NE Iberia): Tectonics, climates, and drainage. Journal of Geophysical Research, 108(B7), 2347. https://doi.org/10.1029/2002JB002073

García-Frank, A., Ureta, S., \& Mas, R. (2008). Aalenian pulses of tectonic activity in the Iberian Basin, Spain. Sedimentary Geology, 209(1-4), 15-35. https://doi.org/10.1016/j.sedgeo.2008.06.004

García-Lasanta, C., Casas-Sainz, A., Villalaín, J. J., Oliva-Urcia, B., Mochales, T., \& Speranza, F. (2017). Remagnetizations used to unravel large-scale fold kinematics: A case study in the Cameros Basin (northern Spain). Tectonics, 36, 714-729. https://doi.org/10.1002/ 2016TC004459

García-Mondéjar, J., Agirrezabala, L. M., Aranburu, A., Fernández-Mendiola, P. A., Gómez-Pérez, I., López-Horgue, M., \& Rosales, I. (1996). Aptian-Albian tectonic pattern of the Basque-Cantabrian Basin (northern Spain). Geological Journal, 31(1), 13-45. https://doi. org/10.1002/(SICI)1099-1034(199603)31:1<13::AID-GJ689>3.0.CO;2-Y

Gautheron, C., Tassan-Got, L., Barbarand, J., \& Pagel, M. (2009). Effect of alpha-damage annealing on apatite (U-Th)/He thermochronology. Chemical Geology, 266(3-4), 157-170. https://doi.org/10.1016/j.chemgeo.2009.06.001

Gautheron, C., Tassan-Got, L., Ketcham, R. A., \& Dobson, K. J. (2012). Accounting for long alpha-particle stopping distances in (U-Th$\mathrm{Sm}$ )/He geochronology: 3D modeling of diffusion, zoning, implantation, and abrasion. Geochimica et Cosmochimica Acta, 96, 44-56. https://doi.org/10.1016/j.gca.2012.08.016

Gibson, M., Sinclair, H. D., Lynn, G. J., \& Stuart, F. M. (2007). Late- to post-orogenic exhumation of the Central Pyrenees revealed through combined thermochronological data and modelling. Basin Research, 19(3), 323-334. https://doi.org/10.1111/j.1365-2117.2007.00333.x

Gleadow, A. J. W., Hurford, A. J., \& Quaife, R. D. (1976). Fission track dating of zircon: Improved etching techniques. Earth and Planetary Science Letters, 33(2), 273-276. https://doi.org/10.1016/0012-821X(76)90235-1

Golberg, J. M., \& Leyreloup, A. F. (1990). High temperature-low pressure Cretaceous metamorphism related to crustal thinning (Eastern North Pyrenean Zone, France). Contributions to Mineralogy and Petrology, 104(2), 194-207. https://doi.org/10.1007/BF00306443

González-Acebrón, L., Arribas, J., Omodeo-Salé, S., Arribas, E., Le Pera, E., Mas, R., et al. (2013). Cyclicity recorded in the provenance sandstones in the sedimentary infill of the Cameros basin (N. Spain). Boletín Geológico y Minero, 124(2), 187-201.

González-Acebrón, L., Goldstein, R., Mas, R., \& Arribas, J. (2011). Criteria for recognition of localization and timing of multiple events of hydrothermal alteration in sandstones illustrated by petrographic, fluid inclusion, and isotopic analysis of the Tera Group, northern Spain. International Journal of Earth Sciences, 100(8), 1811-1826. https://doi.org/10.1007/s00531-010-0606-2 
González-Acebrón, L., Pérez-Garrido, C., Mas, R., Arribas, J., \& Götze, J. (2017). Provenance signatures recorded in transgressive sandstones of the Upper Cretaceous Iberian Seaway. Journal of Sedimentary Research, 87(2), 152-166. https://doi.org/10.2110/jsr.2017.4

Grobe, R. W., Alvarez-Marrón, J., Glasmacher, U. A., \& Menéndez-Duarte, R. (2010). Low-temperature exhumation history of Variscan-age rocks in the western Cantabrian Mountains (NW Spain) recorded by apatite fission-track data. Tectonophysics, 489(1-4), 76-90. https:// doi.org/10.1016/j.tecto.2010.04.006

Guimerà, J. (1988). Estudi estructural de l'Enlaaç entre la Serralada Ibérica i la Serralada costanera Catalana. Barcelona: Universitat de Barcelona.

Guimerà, J., Alonso, Á., \& Mas, J. R. (1995). Inversion of an extensional-ramp basin by a newly formed thrust: The Cameros basin (N. Spain). Geological Society, London, Special Publications, 88(1), 433-453. https://doi.org/10.1144/GSL.SP.1995.088.01.23

Guiraud, M., \& Seguret, M. (1985). A releasing solitary overstep model for the Late Jurassic-Early Cretaceous (Wealdian) Soria strike-slip basin (northern Spain). In K. T. Biddle \& N. Christie-Blick (Eds.), Strike-slip deformation, basin formation, and sedimentation, Society of Economic Paleontologists and Mineralogists (Vol. 37, pp. 159-175). https://doi.org/10.2110/pec.85.37.0143

Gunnell, Y., Calvet, M., Brichau, S., Carter, A., Aguilar, J.-P., \& Zeyen, H. (2009). Low long-term erosion rates in high-energy mountain belts: Insights from thermo- and biochronology in the eastern Pyrenees. Earth and Planetary Science Letters, 278(3-4), 208-218. https:// doi.org/10.1016/j.epsl.2008.12.004

Herman, F., Seward, D., Valla, P. G., Carter, A., Kohn, B., Willett, S. D., \& Ehlers, T. A. (2013). Worldwide acceleration of mountain erosion under a cooling climate. Nature, 504(7480), 423-426. https://doi.org/10.1038/nature12877

Hurford, A. J., \& Green, P. F. (1983). The zeta age calibration of fission-track dating. Chemical Geology, 41, 285-317. https://doi.org/ 10.1016/S0009-2541(83)80026-6

Jammes, S., Manatschal, G., Lavier, L., \& Masini, E. (2009). Tectonosedimentary evolution related to extreme crustal thinning ahead of a propagating ocean: Example of the western Pyrenees. Tectonics, 28, TC4012. https://doi.org/10.1029/2008TC002406

Jammes, S., Tiberi, C., \& Manatschal, G. (2010). 3D architecture of a complex transcurrent rift system: The example of the Bay of Biscaywestern Pyrenees. Tectonophysics, 489(1-4), 210-226. https://doi.org/10.1016/j.tecto.2010.04.023

Jolivet, M., Labaume, P., Monié, P., Brunel, M., Arnaud, N., \& Campani, M. (2007). Thermochronology constraints for the propagation sequence of the south Pyrenean basement thrust system (France-Spain): Propagation of the south pyrenean prism. Tectonics, 26, TC5007. https://doi.org/10.1029/2006TC002080

Juez-Larré, J., \& Andriessen, P. A. M. (2006). Tectonothermal evolution of the northeastern margin of Iberia since the break-up of Pangea to present, revealed by low-temperature fission-track and (U-Th)/He thermochronology: A case history of the Catalan Coastal Ranges. Earth and Planetary Science Letters, 243(1-2), 159-180. https://doi.org/10.1016/j.epsl.2005.12.026

Ketcham, R. A., Gautheron, C., \& Tassan-Got, L. (2011). Accounting for long alpha-particle stopping distances in (U-Th-Sm)/He geochronology: Refinement of the baseline case. Geochimica et Cosmochimica Acta, 75(24), 7779-7791. https://doi.org/10.1016/j.gca.2011.10.011

Ketcham, R., Carter, A., A. Donelick, R., Barbarand, J., \& Hurford, A. J. (2007). Improved modeling of fission-track annealing in apatite. American Mineralogist, 92, 799-810. https://doi.org/10.2138/am.2007.2281

Labaume, P., Meresse, F., Jolivet, M., \& Teixell, A. (2016). Exhumation sequence of the basement thrust units in the west-central Pyrenees. Constraints from apatite fission track analysis. Geogaceta, 60, 11-14.

Lagabrielle, Y., \& Bodinier, J.-L. (2008). Submarine reworking of exhumed subcontinental mantle rocks: Field evidence from the Lherz peridotites, French Pyrenees: Cretaceous exhumation of pyrenean mantle. Terra Nova, 20(1), 11-21. https://doi.org/10.1111/j.13653121.2007.00781.x

Lagabrielle, Y., Labaume, P., \& de Saint Blanquat, M. (2010). Mantle exhumation, crustal denudation, and gravity tectonics during Cretaceous rifting in the Pyrenean realm (SW Europe): Insights from the geological setting of the lherzolite bodies. Tectonics, 29, TC4012. https://doi.org/10.1029/2009TC002588

Lahfid, A., Beyssac, O., Deville, E., Negro, F., Chopin, C., \& Goffé, B. (2010). Evolution of the Raman spectrum of carbonaceous material in low-grade metasediments of the Glarus Alps (Switzerland): RSCM in low-grade metasediments. Terra Nova, 22(5), 354-360. https://doi. org/10.1111/j.1365-3121.2010.00956.x

Lanaja, J. M. (1987). Contribución de la exploración petrolífera al conocimiento de la geología de España. IGME.

Lanari, P., Wagner, T., \& Vidal, O. (2014). A thermodynamic model for di-trioctahedral chlorite from experimental and natural data in the system $\mathrm{MgO}-\mathrm{FeO}-\mathrm{Al} 2 \mathrm{O} 3-\mathrm{SiO} 2-\mathrm{H} 2 \mathrm{O}$ : Applications to $P-T$ sections and geothermometry. Contributions to Mineralogy and Petrology, 167(2). https://doi.org/10.1007/s00410-014-0968-8

Mantilla Figueroa, L. C., Casquet, C., \& Mas, J. R. (1998). Los paleofluidos en el grupo Oncala, cuenca de Cameros (La Rioja, España): datos de inclusiones fluidas, isótopos de oxigeno y SEM. Geogaceta, 24, 207-210.

Mantilla Figueroa, L. C., Galindo, C., Mas, R., \& Casquet, C. (2002). El metamorfismo hidrotermal cretácico y paleógeno en la cuenca de Cameros (Cordillera Ibérica, España). Zubía, 14, 143-154.

Martín-Closas, C. (1989). Els caròfits del Cretaci inferior de les conques perifèriques del bloc de l'Ebre, (Thesis). Universitat de Barcelona, Barcelona.

Martínez-González, R. M., Lago San José, M., Valenzuela Ríos, J. I., Vaquer Navarro, R., \& Salas, R. (1996). El magmatismo alcalino jurásico del sector SE de la Cadena Ibérica: Composición y estructura. Geogaceta, 20(7), 1687-1690.

Marzoli, A., Renne, P., Piccirillo, E., Ernesto, M., Bellieni, G., \& De Min, A. (1999). Extensive 200-million-year-old continental flood basalts of the Central Atlantic magmatic province. Science, 284(5414), 616-618. https://doi.org/10.1126/science.284.5414.616

Mas, J. R., Alonso, A., \& Guimera, J. (1993). Evolución tectonosedimentaria de una cuenca extensional intraplaca: La cuenca fini jurásicaeocretácica de Los Cameros (La Rioja-Soria). Revista de la Sociedad Geológica de España, 6(3-4), 129-144.

Mas, J. R., Moreno, B., Isabel, M., Arribas Mocoroa, J., Alonso Millán, Á., Arribas Mocoroa, M. E., et al., \& others (2011). Evolution of an intra-plate rift basin: The Latest Jurassic-Early Cretaceous Cameros basin (Northwest Iberian Ranges, North Spain). Geo-Guías, 8, 117-155.

Mata, M. P., Casas, A. M., Canals, A., Gil, A., \& Pocovi, A. (2001). Thermal history during Mesozoic extension and Tertiary uplift in the Cameros basin, northern Spain. Basin Research, 13(1), 91-111. https://doi.org/10.1046/j.1365-2117.2001.00138.x

Maurel, O., Moniè, P., Pik, R., Arnaud, N., Brunel, M., \& Jolivet, M. (2008). The Meso-Cenozoic thermo-tectonic evolution of the eastern Pyrenees: An 40>Ar/39Ar fission track and (U-Th)/He thermochronological study of the Canigou and Mont-Louis massifs. International Journal of Earth Sciences, 97(3), 565-584. https://doi.org/10.1007/s00531-007-0179-x

Maurel, O., Respaut, J.-P., Monié, P., Arnaud, N., \& Brunel, M. (2004). U/Pb emplacement and 40Ar/39Ar cooling ages of the eastern Mont-Louis granite massif (eastern Pyrenees, France). Comptes Rendus Geoscience, 336(12), 1091-1098. https://doi.org/10.1016/j.crte.2004.04.005

Metcalf, J. R., Fitzgerald, P. G., Baldwin, S. L., \& Muñoz, J.-A. (2009). Thermochronology of a convergent orogen: Constraints on the timing of thrust faulting and subsequent exhumation of the Maladeta Pluton in the Central Pyrenean Axial Zone. Earth and Planetary Science Letters, 287(3-4), 488-503. https://doi.org/10.1016/j.epsl.2009.08.036 
Morris, R. G., Sinclair, H. D., \& Yelland, A. J. (1998). Exhumation of the Pyrenean orogen: Implications for sediment discharge. Basin Research, 10(1), 69-85. https://doi.org/10.1046/j.1365-2117.1998.00053.x

Mouchene, M. (2016). Evolution post-orogénique du système couplé piémont/bassin versant: le méga cone alluvial de Lannemezan et son bassin versant au Nord des Pyrénées. Université Grenoble Alpes.

Mouthereau, F., Filleaudeau, P.-Y., Vacherat, A., Pik, R., Lacombe, O., Fellin, M. G., et al. (2014). Placing limits to shortening evolution in the Pyrenees: Role of margin architecture and implications for the Iberia/Europe convergence. Tectonics, 33, 2283-2314. https://doi.org/ $10.1002 / 2014 \mathrm{TC} 003663$

Muñoz-Jiménez, A., \& Casas-Sainz, A. M. (1997). The Rioja Trough (N Spain): Tectosedimentary evolution of a symmetric foreland basin Basin Research, 9(1), 65-85. https://doi.org/10.1046/j.1365-2117.1997.00031.x

Murillas, J., Mougenot, D., Boulot, G., Comas, M., Banda, E., \& Mauffret, A. (1990). Structure and evolution of the Galicia Interior Basin (Atlantic western Iberian continental margin). Tectonophysics, 184(3-4), 297-319. https://doi.org/10.1016/0040-1951(90)90445-E

Naeser, C. W., Zeitler, P., \& Cerveny, P. (1987). Provenance studies by fission track dating-etching and counting procedures. International Journal of Radiation Applications and Instrumentation. Part D. Nuclear Tracks and Radiation Measurements, 13(2-3), 121-126. https:// doi.org/10.1016/1359-0189(87)90022-7

Nirrengarten, M., Manatschal, G., Tugend, J., Kusznir, N., \& Sauter, D. (2018). Kinematic evolution of the southern North Atlantic: Implications for the formation of hyperextended rift systems. Tectonics, 37, 89-118. https://doi.org/10.1002/2017TC004495

Nirrengarten, M., Manatschal, G., Tugend, J., Kusznir, N. J., \& Sauter, D. (2017). Nature and origin of the J-magnetic anomaly offshore Iberia-Newfoundland: Implications for plate reconstructions. Terra Nova, 29(1), 20-28. https://doi.org/10.1111/ter.12240

Ochoa, M., Arribas, J., Mas, R., \& Goldstein, R. H. (2007). Destruction of a fluvial reservoir by hydrothermal activity (Cameros Basin, Spain). Sedimentary Geology, 202(1-2), 158-173. https://doi.org/10.1016/j.sedgeo.2007.05.017

Olivet, J. L. (1996). La cinématique de la plaque Ibérique. Elf Explo.

Omodeo Salè, S., Guimerà, J., Mas, R., \& Arribas, J. (2014). Tectono-stratigraphic evolution of an inverted extensional basin: The Cameros Basin (north of Spain). International Journal of Earth Sciences, 103(6), 1597-1620. https://doi.org/10.1007/s00531-014-1026-5

Omodeo-Salé, S., Salas, R., Guimerà, J., Ondrak, R., Mas, R., Arribas, J., Suárez-Ruiz, I., et al. (2017). Subsidence and thermal history of an inverted Late Jurassic-Early Cretaceous extensional basin (Cameros, north-central Spain) affected by very low- to low-grade metamorphism. Basin Research, 29, 156-174. https://doi.org/10.1111/bre.12142

Omodeo-Salé, S., Suárez-Ruiz, I., Arribas, J., Mas, R., Martínez, L., \& Herrero, M. J. (2016). Characterization of the source rocks of a paleopetroleum system (Cameros Basin) based on organic matter petrology and geochemical analyses. Marine and Petroleum Geology, 71 , 271-287. https://doi.org/10.1016/j.marpetgeo.2016.01.002

Ortí, F., Pérez-López, A., \& Salvany, J. M. (2017). Triassic evaporites of Iberia: Sedimentological and palaeogeographical implications for the western Neotethys evolution during the Middle Triassic-Earliest Jurassic. Palaeogeography, Palaeoclimatology, Palaeoecology, 471, 157-180. https://doi.org/10.1016/j.palaeo.2017.01.025

Ortí, F., \& Vaquer, R. (1980). Volcanismo jurásico del sector valenciano de la Cordillera Ibérica. Distribución y trama estructural. Acta Geologica Hispánica, 15(5), 127-130.

Pedrera, A., García-Senz, J., Ayala, C., Ruiz-Constán, A., Rodríguez-Fernández, L. R., Robador, A., \& González Menéndez, L. (2017). Reconstruction of the exhumed mantle across the north Iberian margin by crustal-scale 3-D gravity inversion and geological cross section: Mantle along the Basque-Cantabrian Basin. Tectonics, 36, 3155-3177. https://doi.org/10.1002/2017TC004716

Péron-Pinvidic, G., Manatschal, G., Minshull, T. A., \& Sawyer, D. S. (2007). Tectonosedimentary evolution of the deep IberiaNewfoundland margins: Evidence for a complex breakup history: Iberia-Newfoundland breakup history. Tectonics, 26, TC2011. https:// doi.org/10.1029/2006TC001970

Press, W. H., Teukolsly, S. A., Vetterling, W. T., \& Flannery, B. P. (1992). Numerical recipes in FORTRAN (2nd ed.). New York: Cambridge University Press.

Puigdefàbregas, C., Muñoz, J. A., \& Vergés, J. (1992). Thrusting and foreland basin evolution in the southern Pyrenees. In Thrust Tectonics (pp. 247-254). Dordrecht: Springer. https://doi.org/10.1007/978-94-011-3066-0_22

Puigdefàbregas, C., \& Souquet, P. (1986). Tecto-sedimentary cycles and depositional sequences of the Mesozoic and Tertiary from the Pyrenees. Tectonophysics, 129(1-4), 173-203. https://doi.org/10.1016/0040-1951(86)90251-9

Quijada, I. E., Suárez González, P., Benito Moreno, M. I., Mas Mayoral, J. R., Alonso Millán, Á., Suárez González, P., et al. (2010). Un ejemplo de llanura fluvio-deltaica influenciada por las mareas: el yacimiento de icnitas de Serrantes (Grupo Oncala, Berriasiense, Cuenca de Cameros, N. de España). Geogaceta, 49, 15-18.

Rasmussen, E. S., Lomholt, S., Andersen, C., \& Vejbæk, O. V. (1998). Aspects of the structural evolution of the Lusitanian Basin in Portugal and the shelf and slope area offshore Portugal. Tectonophysics, 300(1-4), 199-225. https://doi.org/10.1016/S0040-1951(98)00241-8

Rat, P. (1988). The Basque-Cantabrian Basin between the Iberian and European plates some facts but still many problems. Revista de la Sociedad Geológica de España, 1, 327-348.

Roca, E., \& Guimerà, J. (1992). The Neogene structure of the eastern Iberian margin: Structural constraints on the crustal evolution of the Valencia trough (western Mediterranean). Tectonophysics, 203(1-4), 203-218. https://doi.org/10.1016/0040-1951(92)90224-T

Rougier, G., Ford, M., Christophoul, F., \& Bader, A.-G. (2016). Stratigraphic and tectonic studies in the central Aquitaine Basin, northern Pyrenees: Constraints on the subsidence and deformation history of a retro-foreland basin. Comptes Rendus Geoscience, 348(3-4), 224-235. https://doi.org/10.1016/j.crte.2015.12.005

Rushlow, C. R., Barnes, J. B., Ehlers, T. A., \& Vergés, J. (2013). Exhumation of the southern Pyrenean fold-thrust belt (Spain) from orogenic growth to decay: Exhumation of the southern Pyrenees. Tectonics, 32, 843-860. https://doi.org/10.1002/tect.20030

Salas, R., Caja, M. A., Martín, J. D., Mas, R., \& Permanyer, A. (2005). Mid-Late Cretaceous volcanism, metamorphism and the regional thermal event affecting the Northeastern Iberian basins (Spain). In Global Events during the Quiet Aptian-Turonian Superchron. Laboratoire de Géologie de lUniversité I de Grenoble, Geologie Alpine, Série Spéciale, 2005, no 6 (pp. 55-58).

Salas, R., \& Casas, A. (1993). Mesozoic extensional tectonics, stratigraphy and crustal evolution during the Alpine cycle of the eastern Iberian basin. Tectonophysics, 228(1-2), 33-55. https://doi.org/10.1016/0040-1951(93)90213-4

Salas, R., Martin-Closas, C., \& Querol, X. G. (1995). Evolución tectonosedimentaria de las cuencas del Maestrazgo y Aliaga-Penyagolosa durante el Cretacico inferior. El Cretacico Inferior Del Nordeste de Iberia (pp. 13-94).

Salas, R., Guimerà, J., Mas, R., Martín-Closas, C., Melendez, A., \& Alonso, Á. (2001). Evolution of the Mesozoic central Iberian rift system and its Cainozoic inversion (Iberian chain). Memoires Du Museum National d'Histoire Naturelle, 186, 145-186.

Schettino, A., \& Turco, E. (2011). Tectonic history of the western Tethys since the Late Triassic. Bulletin, 123(1-2), 89-105.

Schudack, M. (1987). Charophytenflora und fazielle Entwicklung der Grenzschichten mariner Jura/Wealden in den nordwestlichen iberischen Ketten (mit Vergleichen zu Asturien und Kantabrien). Palaeontographica Abteilung B, 204, 1-80. 
Sinclair, H. D., Gibson, M., Naylor, M., \& Morris, R. G. (2005). Asymmetric growth of the Pyrenees revealed through measurement and modeling of orogenic fluxes. American Journal of Science, 305(5), 369-406. https://doi.org/10.2475/ajs.305.5.369

Stampfli, G. M., \& Borel, G. D. (2002). A plate tectonic model for the Paleozoic and Mesozoic constrained by dynamic plate boundaries and restored synthetic oceanic isochrons. Earth and Planetary Science Letters, 196(1-2), 17-33. https://doi.org/10.1016/S0012821X(01)00588-X

Suárez González, P., Quijada, I. E., Mas, J. R., \& Benito, M. I. (2010). Nuevas aportaciones sobre la influencia marina y la edad de los carbonatos de la Fm Leza en el sector de Préjano (SE de La Rioja). Cretácico Inferior, Cuenca de Cameros. Geogaceta, 49, 7-10.

Suárez-González, P., Benito, M. I., Mas, J. R., Quijada, I. E., \& Campos-Soto, S. (2016). Influencia del Keuper y de la estructuración tardivarisca en la arquitectura de las unidades sin-extensionales del borde norte de la Cuenca de Cameros. Geo-Temas, 16, $185-188$.

Tagami, T., Galbraith, R. F., Yamada, R., \& Laslett, G. M. (1998). Revised annealing kinetics of fission tracks in zircon and geological implications. In Advances in fission-track geochronology (pp. 99-112). Dordrecht: Springer. https://doi.org/10.1007/978-94015-9133-1_8

Tischer, G. (1966). El delta Wealdico de las montañas Ibéricas Occidentales y sus enlaces tectonicos. Notas y Comunicaciones Instituto Geologico y Minero de España, 81, 53-78.

Tucholke, B. E., Sawyer, D. S., \& Sibuet, J.-C. (2007). Breakup of the Newfoundland Iberia rift. Geological Society, London, Special Publications, 282(1), 9-46. https://doi.org/10.1144/SP282.2

Tugend, J., Manatschal, G., \& Kusznir, N. J. (2015). Spatial and temporal evolution of hyperextended rift systems: Implication for the nature, kinematics, and timing of the Iberian-European plate boundary. Geology, 43(1), 15-18. https://doi.org/10.1130/G36072.1

Tugend, J., Manatschal, G., Kusznir, N. J., Masini, E., Mohn, G., \& Thinon, I. (2014). Formation and deformation of hyperextended rift systems: Insights from rift domain mapping in the Bay of Biscay-Pyrenees. Tectonics, 33, 1239-1276. https://doi.org/10.1002/ 2014TC003529

Ureta, S. (1985). Bioestratigrafía y Paleontología (Ammonitina) del Aaleniense en el Sector Noroccidental de la Cordillera Ibérica. Universitat de Madrid.

Vacherat, A., Mouthereau, F., Pik, R., Bellahsen, N., Gautheron, C., Bernet, M., et al. (2016). Rift-to-collision transition recorded by tectonothermal evolution of the northern Pyrenees: Cooling history of the northern Pyrenees. Tectonics, 35, 907-933. https://doi.org/ $10.1002 / 2015$ TC004016

Vacherat, A., Mouthereau, F., Pik, R., Bernet, M., Gautheron, C., Masini, E., et al. (2014). Thermal imprint of rift-related processes in orogens as recorded in the Pyrenees. Earth and Planetary Science Letters, 408, 296-306. https://doi.org/10.1016/j.epsl.2014.10.014

Vacherat, A., Mouthereau, F., Pik, R., Huyghe, D., Paquette, J.-L., Christophoul, F., et al. (2017). Rift-to-collision sediment routing in the Pyrenees: A synthesis from sedimentological, geochronological and kinematic constraints. Earth-Science Reviews, 172(Supplement C), 43-74. https://doi.org/10.1016/j.earscirev.2017.07.004

Van Hinsbergen, D. J. J., Vissers, R. L. M., \& Spakman, W. (2014). Origin and consequences of western Mediterranean subduction, rollback, and slab segmentation. Tectonics, 33, 393-419. https://doi.org/10.1002/2013TC003349

Vergés, J., \& García-Senz, J. (2001). Mesozoic evolution and Cainozoic inversion of the Pyrenean Rift. In P. A. Ziegler, W. Cavazza, A. H. F. Robertson, \& S. Crasquin-Soleau (Eds.), Peri-Tethys Memoir (Vol. 6, pp. 187-212).

Vermeesch, P. (2009). RadialPlotter: A Java application for fission track, luminescence and other radial plots. Radiation Measurements, 44(4), 409-410.

Vidal, O., Parra, T., \& Trotet, F. (2001). A thermodynamic model for Fe-Mg aluminous chlorite using data from phase equilibrium experiments and natural pelitic assemblages in the $100^{\circ}$ to $600^{\circ} \mathrm{C}, 1$ to $25 \mathrm{~kb}$ range. American Journal of Science, 301(6), 557-592. https:// doi.org/10.2475/ajs.301.6.557

Vissers, L. M., van Hinsbergen, J. J., van der Meer, G., \& Spakman, W. (2016). Cretaceous slab break-off in the Pyrenees: Iberian plate kinematics in paleomagnetic and mantle reference frames. Gondwana Research, 34, 49-59. https://doi.org/10.1016/j.gr.2016.03.006

Vissers, R. L. M., \& Meijer, P. T. (2012). Mesozoic rotation of Iberia: Subduction in the Pyrenees? Earth-Science Reviews, 110(1-4), 93-110. https://doi.org/10.1016/j.earscirev.2011.11.001

Whitchurch, A. L., Carter, A., Sinclair, H. D., Duller, R. A., Whittaker, A. C., \& Allen, P. A. (2011). Sediment routing system evolution within a diachronously uplifting orogen: Insights from detrital zircon thermochronological analyses from the south-central Pyrenees. American Journal of Science, 311(5), 442-482. https://doi.org/10.2475/05.2011.03

Wilde, S. (1990). The Bathonian and Callovian of the Northwest-lberian Range: Stages of facial paleogeographical differentiation on an epicontinental platform. Cuadernos de Geología Ibérica= Journal of Iberian Geology: An International Publication of Earth Sciences, 14, 113-142.

Yamada, R., Murakami, M., \& Tagami, T. (2007). Statistical modelling of annealing kinetics of fission tracks in zircon; reassessment of laboratory experiments. Chemical Geology, 236(1-2), 75-91. https://doi.org/10.1016/j.chemgeo.2006.09.002

Yelland, A. J. (1990). Fission track thermotectonics in the Pyrenean orogen. International Journal of Radiation Applications and Instrumentation. Part D. Nuclear Tracks and Radiation Measurements, 17(3), 293-299. https://doi.org/10.1016/1359-0189(90)90049-4 Yelland, A. J. (1991). Thermo-tectonics of the Pyrenees and provence from fission track studies, (PhD thesis). University of London. Zielger, P. (1989). Evolution of the Arctic-North Atlantic and the Western Tethys. United States. 